Article

\title{
The Effects of Coke Parameters and Circulating Flue Gas Characteristics on NOx Emission during Flue Gas Recirculation Sintering Process
}

\author{
Juntao Han ${ }^{1}$, Guofeng Lou ${ }^{1,2, *}$, Sizong Zhang ${ }^{1}$, Zhi Wen ${ }^{1,2}$, Xunliang Liu ${ }^{1,2}$ and Jiada Liu ${ }^{1}$ \\ 1 School of Energy and Enviromental Engineering, University of Science \& Technology Beijing, \\ Beijing 100083, China \\ 2 Beijing Key Laboratory of Energy Saving and Emission Reduction for Metallurgical Industry, \\ University of Science \& Technology Beijing, Beijing 100083, China \\ * Correspondence: lgf@ustb.edu.cn
}

Received: 1 September 2019; Accepted: 2 October 2019; Published: 10 October 2019

\begin{abstract}
The new process of flue gas recirculation, which reduces coke consumption and reducing NOx emissions, is now extensively used. Compared with traditional sintering, the characteristics of circulating flue gas and coke parameters significantly affect the combustion atmosphere and coke combustion efficiency. Based on the actual complex process of sintering machine, this study proposes a relatively comprehensive one-dimensional, unsteady mathematical model for flue gas recirculation research. The model encompasses NOx pollutant generation and reduction, as well as $\mathrm{SO}_{2}$ generation and adsorption. We focus on the effects of cyclic flue gas characteristics on the sintering-bed temperature and NOx emissions, which are rarely studied, and provide a theoretical basis for NOx emission reduction. Simulation results show that during sintering, the fuel NOx is reduced by $50 \%$ and $10 \%$ when passing through the surface of coke particles and CO, respectively. During flue gas recirculation sintering, the increase in circulating gas $\mathrm{O}_{2}$ content, temperature, and supply-gas volume cause increased combustion efficiency of coke, reducing atmosphere, and NOx content in the circulating area; the temperature of the material layer also increases significantly and the sintering endpoint advances. During cyclic sintering, the small coke size and increased coke content increase the char-N release rate while promoting sufficient contact of NOx with the coke surface. Consequently, the NOx reduction rate increases. Compared with the conventional sintering, the designed flue gas recirculation condition saves $3.75 \%$ of coke consumption, i.e., for $1.2 \mathrm{~kg}$ of solid fuel per ton of sinter, the amount of flue gas treatment is reduced by $21.64 \%$ and NOx emissions is reduced by $23.59 \%$. Moreover, without changing the existing sintering equipment, sintering capacity increases by about $5.56 \%$.
\end{abstract}

Keywords: numerical simulation; flue gas recirculation; coke combustion; NOx emission

\section{Introduction}

Since NOx is the root cause of photochemical smog and acid rain, it causes serious environmental and ecological problems. Relevant emission regulations are continuously being improved given the global significance of controlling NOx emissions. Among these emissions, those from the steel industry account for about $6 \%$ of the overall emissions of all industries. Moreover, $\mathrm{SO}_{2}$ and $\mathrm{NOx}$ emissions during sintering account for $60 \%$ and $50 \%$ of the overall emissions of $\mathrm{SO}_{2}$ and $\mathrm{NOx}$ in steel production, respectively [1]. At present, new technologies for reducing NOx emission during sintering mainly include flue gas recirculation sintering (FGRS), selective catalytic reduction [2], biomass fuel [3-6], gas injection [7], and parameter control [8,9]. 
In recent years, some scholars have experimentally studied the emission law of NOx in iron-ore sintering, focusing on the effects of using biomass-fuel substitution (e.g., charcoal, burned straw, and sawdust), different types of coke particles, coke preform, and calcium ferrite and $\mathrm{CeO}_{2}$ catalytic reduction on the overall emission of NOx $[10,11]$. Some studies have focused on the effects of the flue gas concentration around coke particles on char- $\mathrm{N}$ conversion and NOx reduction [12]. Over the past two decades, various FGRS schemes have been proposed to reduce pollutant emissions and improve energy efficiency. Chen et al. [13] improved the coke-combustion efficiency by flue gas recirculation to reduce NOx emission, when using $\mathrm{CeO}_{2}$ modified coke and flue gas recirculation for sintering pot simulation, and the NOx reduction rate is $38.0 \%$. Fan et al. [14,15] performed a sintering-pot test and found that flue gas recycling contributes partly to $\mathrm{NOx}$ reduction in the sintering bed layer. $\mathrm{SO}_{2}$ is absorbed and filtered by the mixed layer, $\mathrm{CO}$ is reused as fuel, and the production of iron ore per ton can reduce NOx by $20 \%-45 \%$, dioxins by $60 \%-70 \%$ and $\mathrm{SO}_{2}$ by $20 \%-45 \%$ [16], which proves that flue gas recycling can effectively reduce pollutant emissions. Although some research on the mechanism of NOx formation and reduction during sintering has been conducted, these processes are complicated, so further research is needed. However, many studies have focused on the combustion behavior and heat transfer in iron-ore sintering, particularly the influences of fuel ratio, gas supply, coke size, limestone particle size, and different exhaust-gas cycle schemes on sintering [17-20]. Some papers have reported mathematical models and key parameters for NOx behavior in conventional sintering (CS) $[21,22]$. Few studies have been conducted on the numerical simulation of iron-ore FGRS, especially on the influence of operating parameters on NOx emissions during actual FGRS. In flue gas recirculation, flue gas is mixed with air as the input condition, compared with CS, flue gas recirculation technology has the advantages of low solid-fuel consumption, NOx re-reduction, and improved efficiency of flue gas treatment in the late stage. However, due to the different locations of the circulating region, varied sources of circulating gases, and the change in the bed layer structure during combustion, the main input parameters of flue gas circulation are changed. These parameters include $\mathrm{O}_{2}$ content, gas supply, and circulating-gas temperature. Moreover, the combustion atmosphere is quite different from that of CS, the heat and mass transfer process between gas and solid phases, and the combustion efficiency of coke in the sintering area are affected significantly, as well as the release and reductive process of char-N.

In the present study, a one-dimensional unsteady mathematical model based on the heat transfer, mass transfer, and complex physical and chemical changes in iron-ore sintering $[23,24]$ is established. The reliability of the mathematical model has been verified by sintering pot tests. The effects of key input conditions (i.e., $\mathrm{O}_{2}$ content and gas temperature and gas supply of the recirculation hood) and coke parameters on bed temperature and contents of $\mathrm{NOx}, \mathrm{O}_{2}$, and $\mathrm{CO}$ in flue gas during sintering were quantified. The effectiveness of FGRS in reducing solid-fuel consumption, flue gas treatment, and NOx emissions is also discussed and compared with CS. The effects of the main operating parameters on NOx emission during recirculation sintering is explored, and a theoretical basis for the optimization of flue gas recirculation is provided.

\section{Mathematical Model of Sintering}

After the sinter is batched, mixed, granulated, charged, and ignited, sintering begins. Considering that the temperature in the width direction of the bed layer is substantially the same and the running speed is slow, the actual sintering can be regarded as a one-dimensional porous-medium transmission process. The transmission in the width and the running direction is ignored. In order to reveal the heat and mass transfer, multi-reaction coupling and NOx emission mechanism of flue gas recirculation process. The model considers relatively complete homogeneous, heterogeneous reactions and changes in the structural parameters of the bed layer; it also considers convective heat transfer and heat conduction between gas-solid phases, radiation heat transfer between solid phases, and the modification of initial particle size distribution of raw materials to the overall reaction rate of the reaction submodel. 


\subsection{Governing Equations}

The sintered layer includes solid-phase components of iron ore $\left(\mathrm{Fe}_{2} \mathrm{O}_{3}, \mathrm{Fe}_{3} \mathrm{O}_{4}\right.$, and $\left.\mathrm{Fe}\right)$, coke particles, return fines and flux agent (limestone, dolomite, and hydrated lime), and physical water and gas-phase components $\left(\mathrm{O}_{2}, \mathrm{NOx}, \mathrm{CO}_{2}, \mathrm{CO}\right.$, and $\mathrm{H}_{2} \mathrm{O}$ [g]). The following list provides governing equations that describe heat transfer, mass transfer, and gas flow during iron ore sintering.

The conservation equations for the solid and gas phase components are as follows $[25,26]$.

$$
\begin{gathered}
\frac{\partial\left((1-\varepsilon) \rho_{s} u_{s} \cdot Y_{j}\right)}{\partial x}+\frac{\partial\left((1-\varepsilon) \rho_{s} \cdot Y_{j}\right)}{\partial t}=-\sum_{k} \sum_{j} M_{j, k} R_{j, k}, \\
\frac{\partial\left(\varepsilon \rho_{g} u_{g} \cdot \gamma_{i}\right)}{\partial x}+\frac{\partial\left(\varepsilon \rho_{g} \cdot \gamma_{i}\right)}{\partial t}=\sum_{k} \sum_{i} M_{i, k} R_{i, k} .
\end{gathered}
$$

The pressure drop in the sintered bed is iteratively calculated using the Ergun equation for given geometric parameters and gas flow rates. The momentum conservation equation is expressed as follows [27].

$$
\frac{P}{\Delta H}=323 \frac{\mu}{\left(\varsigma_{j} d_{p}\right)^{2}} \frac{(1-\varepsilon)^{2}}{\varepsilon^{3}} u_{g}+3.78 \frac{\rho_{g}}{\varsigma_{j} d_{p}} \frac{1-\varepsilon}{\varepsilon^{3}} u_{g}^{2} .
$$

Solid phase and gas phase energy conservation are as follows [26,28].

$$
\begin{gathered}
\frac{\partial\left((1-\varepsilon) u_{s} \rho_{s} C_{p s} T_{s}\right)}{\partial x}+\frac{\partial\left((1-\varepsilon) \rho_{s} C_{p s} T_{s}\right)}{\partial t}=\frac{\partial}{\partial x}\left(\lambda_{s, t o t a l} \frac{\partial T_{s}}{\partial x}\right)+h_{\text {conv }} A_{s s a}\left(T_{g}-T_{s}\right)+\sum_{k} M_{k} R_{k}\left(\Delta H_{k}-C_{p s} T_{s}\right), \\
\frac{\partial\left(\varepsilon \rho_{g} C_{p g} u_{g} T_{g}\right)}{\partial x}+\frac{\partial\left(\varepsilon \rho_{g} C_{p g} T_{g}\right)}{\partial t}=\frac{\partial}{\partial x}\left(\varepsilon \lambda_{g} \frac{\partial T_{g}}{\partial x}\right)+h_{\text {conv }} A_{s s a}\left(T_{s}-T_{g}\right)+\sum_{k} M_{k} R_{k} C_{p s} T_{s} .
\end{gathered}
$$

\subsection{Main Reaction Models}

Throughout the entire sintering process from charging ignition to unloading, each sinter layer undergoes heterogeneous reactions such as gasification and combustion of solid fuel, drying and volatilization, thermal decomposition of limestone, thermal dissociation of slaked lime, reduction of iron oxides, and mineral melting and consolidation.

\subsubsection{Gasification and Combustion of Solid Fuel}

Coke is the main solid fuel used in the iron ore sintering, the combustion process consists of several elementary reactions. Coke combustion is an important parameter that determines the maximum temperature and flame thickness in the sinter, and the reaction equation is shown as Equation (6). The unreacted shrinkage model is used to describe the combustion process of coke particles. The combustion rate depends on the mass transfer in the film boundary layer, chemical reaction, and ash diffusion process. The reaction rate is Equation (7) [29,30].

$$
\begin{aligned}
& \mathrm{\kappa C}+\mathrm{O}_{2} \rightarrow(2-\kappa) \mathrm{CO}_{2}+2(\mathrm{\kappa}-1) \mathrm{CO}, \\
& R_{\text {coke }}=\frac{n_{c} \cdot 4 \pi r_{c}^{2} C_{\mathrm{O}_{2}}}{\frac{1}{\xi \cdot k_{c}}+\frac{\varsigma_{j} d p}{S h \cdot D_{\mathrm{CO}_{2}, e f f}}+\frac{\delta}{\varepsilon_{j} e^{-B \delta \cdot D_{\mathrm{O}_{2}}}}},
\end{aligned}
$$

where $k_{c}=1.715 \cdot T_{s} \cdot \exp \left(-74830 / R_{g} T_{s}\right), S h=2+0.7 \operatorname{Re}^{0.7} S c^{0.33}, \delta=r_{0}-r_{c}$. 


\subsubsection{Evaporation and Condensation of Water}

The water content of the sintered raw material after mixing is generally $8 \%-12 \%$. Evaporation and condensation occur in the preheating drying zone and the excessive wet zone of the sintered layer. Moreover, the reaction equation is $\mathrm{H}_{2} \mathrm{O}(\mathrm{l}) \rightarrow \mathrm{H}_{2} \mathrm{O}(\mathrm{g})$. The evaporation of water is mainly controlled by the actual partial pressure of water vapor on the surface of the solid-phase material and the saturated water vapor pressure at that temperature. The evaporation and condensation rates are expressed as follows [24,25]:

$$
\begin{aligned}
& R_{d r y}=\chi \cdot \beta_{\mathrm{H}_{2} \mathrm{O}} \cdot A_{s s a} / R_{g} T_{g}\left(P_{\mathrm{H}_{2} \mathrm{O}}^{*}-P_{\mathrm{H}_{2} \mathrm{O}}\right) \\
& R_{\text {conden }}=\beta_{\mathrm{H}_{2} \mathrm{O}} \cdot A_{\text {ssa }} / R_{g} T_{g}\left(P_{\mathrm{H}_{2} \mathrm{O}}-P_{\mathrm{H}_{2} \mathrm{O}}^{*}\right),
\end{aligned}
$$

where $\chi=\min \left(1,1-(1-w)\left(1-1.796 w+1.0593 w^{2}\right)\right)$, and $P^{\prime}{ }_{H_{2} O}=\exp \left(25.541-5211 / T_{s}\right)$.

\subsubsection{Thermal Decomposition of Limestone}

Limestone is the main flux in the sintering process. The decomposition reaction of limestone occurs when the bed temperature increases to the decomposition temperature during sintering. The reaction equation and rate are modeled as Equations (9) and (10) [31].

$$
\begin{aligned}
& \mathrm{CaCO}_{3}(\mathrm{~s}) \rightarrow \mathrm{CaO}(\mathrm{s})+\mathrm{CO}_{2}(\mathrm{~g}), \\
& R_{\text {limist }}=\frac{n_{\mathrm{L}} \cdot 4 \pi r_{c}^{2}\left(C_{\mathrm{CO}_{2}}^{*}-C_{\mathrm{CO}_{2}}\right)}{\frac{\varsigma_{j} d p}{S h \cdot D_{\mathrm{CO}_{2}, e f f}}+\frac{d_{0} \cdot 2 \delta}{d_{c} \varepsilon_{j}^{1.41} \cdot D_{\mathrm{CO}_{2}}}+\left(\frac{d_{0}}{d_{c}}\right)^{2} \frac{4.1868 K_{\text {eq }}}{k_{c} R_{g} T_{s}}},
\end{aligned}
$$

where $K_{e q}=101325 \cdot \exp (7.0099-8202.5 / T s), \mathrm{k}_{c}=1520 \cdot \exp \left(-20143.4 / T_{s}\right), C_{C O 2}=K_{e q} /\left(1000 R_{g} T_{s}\right)$.

\subsubsection{Thermal Dissociation of Slaked Lime}

Slaked lime is derived from quicklime $(\mathrm{CaO})$ and physical water added in the sintering raw material, and the reaction releases considerable heat that can effectively raise the temperature of the mixture and improve the gas permeability of the layer. The reaction equation and rate are presented as Equations (11) and (12), respectively [32].

$$
\begin{gathered}
\mathrm{Ca}(\mathrm{OH})_{2}(\mathrm{~s}) \rightarrow \mathrm{CaO}(\mathrm{s})+\mathrm{H}_{2} \mathrm{O}(\mathrm{g}), \\
R_{\text {diss }}=1.18 \times 10^{18} \exp \left(\frac{-280400}{R_{g} T_{s}}\right) \cdot\left(P * \exp \left(\frac{-138500}{R_{g} T_{s}}\right) / R_{g} T_{s}\right) \cdot S_{0} m_{c}
\end{gathered}
$$

where $S_{0}=(8.3 \pm 1) \times 10^{3} \mathrm{~m}^{2} \cdot \mathrm{kg}^{-1}, p *=1.834 \times 10^{8} \mathrm{~atm}$.

\subsubsection{Reduction of Iron Oxides}

The mixture of the sintered bed contains iron oxide. Given the presence of a reducing atmosphere, the iron oxide is easily reduced by $\mathrm{CO}$, and the influence on the temperature field and gas component distribution in the sintering bed must be considered. The present study considered three stages of iron oxide reduction, that is, Equation (13). The reaction rate at each stage was calculated using Equation (14) [33].

$$
\begin{gathered}
3 \mathrm{Fe}_{2} \mathrm{O}_{3}(\mathrm{~s}) \rightarrow 2 \mathrm{Fe}_{3} \mathrm{O}_{4}(\mathrm{~s}) \rightarrow 6 \mathrm{FeO}(\mathrm{s}) \rightarrow 6 \mathrm{Fe}(\mathrm{s}), \\
R_{\text {reduc }}=k_{i} \cdot\left(m_{0}^{1 / 3}-m_{c}^{1 / 3}\right)^{2} \cdot m_{0}^{1 / 3}(i=1,2,3),
\end{gathered}
$$

where $k_{1}=1.32 \times 10^{6} \exp \left(-\frac{114000}{R_{g} T_{s}}\right), k_{2}=3.06 \times 10^{5} \exp \left(-\frac{68600}{R_{g} T_{s}}\right), k_{3}=1.91 \times 10^{5} \exp \left(-\frac{66000}{R_{g} T_{s}}\right)$. 


\subsubsection{Melting and Consolidation of Minerals}

Melting and consolidation of minerals are the main factors that affect the structure and particle morphology of the sintered bed. The transformation process can be described as "solid-phase material $\rightarrow$ molten liquid phase $\rightarrow$ solidified phase." The initial temperature of the melting is related to the composition of the solid-phase mixture. The melting initiation temperature and melting rate are expressed as follows [25].

$$
\begin{aligned}
& T_{m, i n i}=1380+21.22 \mathrm{Al}_{2} \mathrm{O}_{3}+3.35 \mathrm{SiO}_{2}-1.8 \mathrm{flux} \\
& R_{\text {melt }}=0.001 \cdot\left(\mathrm{T}_{s}-\mathrm{T}_{m, \text { ini }}\right) \cdot \rho_{s} .
\end{aligned}
$$

\subsection{NOx Generation and Reduction Model}

The particle size of solid fuel coke during iron-ore sintering is generally $0-5 \mathrm{~mm}$, which is similar to that of coal powder in a fluidized bed but relatively different from that in a pulverized coal furnace. The flue gas produced by coke combustion stays longer in the pore and coke-surface powder than does that produced by pulverized coal combustion, and the former is more conducive to NOx reduction. The temperature during sintering generally does not exceed $1400^{\circ} \mathrm{C}$, and thermal NOx forms through $\mathrm{N}_{2}$ oxidation in air at high temperature. When the temperature is lower than $1800 \mathrm{~K}$, almost no thermal NOx is generated. Therefore, the models considered in the FGRS include mostly fuel NOx formation and reduction by coke particles and CO. Figure 1 shows the char-N conversion process during combustion.

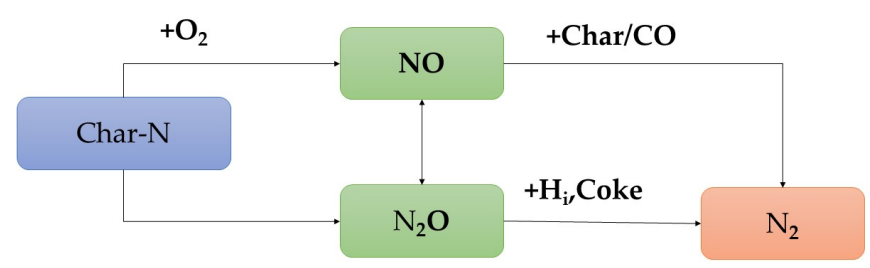

Figure 1. Conversion of char-N during combustion.

\subsubsection{Fuel NOx Formation Model}

The solid fuel in iron-ore sintering primarily comprises coke particles and a small amount of anthracite. The volatile content is generally $1 \%-2 \%$, so the NOx generated by volatiles is neglected and only char- $\mathrm{N}$ conversion is considered. After the coke particles begin to burn, char- $\mathrm{N}$ is oxidized to form NOx. According to previous research, the reaction equation is Char- $\mathrm{N}+\mathrm{O}_{2} \rightarrow \mathrm{NOx}$. The fuel NOx formation rate adopts the following model $[21,34]$.

$$
R_{\mathrm{NO}, f}=\varphi \frac{\eta Y_{N} M_{N O}}{M_{N}} R_{c}
$$

\subsubsection{NOx Reduction Model}

During iron ore sintering, the $\mathrm{N}$ on the surface of the coke particles reacts with $\mathrm{O}_{2}$ to form NOx. The generated NOx diffuses, and some are adsorbed on the surface of coke particles to react with their active groups. Combined with previous experiments $[21,35,36]$ and simulation studies, the reaction of $\mathrm{NO}$ with coke particles at high temperature is the first-order reaction of NO. The reaction equation of coke particle with $\mathrm{NO}$ is Char- $\mathrm{C}+\mathrm{NO} \rightarrow \mathrm{N}_{2}+\mathrm{C}(\mathrm{O})$. The reaction rate of single coke particle with $\mathrm{NO}$ is as follows.

$$
R_{N O, c}=\eta k_{N O, c} P_{N O} S_{c}
$$

where $k_{N O, c}=0.0045 \times \exp \left(-144000 / R_{g} T_{s}\right)$.

Previous studies have shown that during sintering, coke can react with $\mathrm{NO}$ in the combustion zone, and $\mathrm{CaO}, \mathrm{MgO}$, and metal oxide have a certain catalytic effect on the $\mathrm{CO}$ reduction of $\mathrm{NO}$. 
The reaction is $\mathrm{NO}+\mathrm{CO} \rightarrow 0.5 \mathrm{~N}_{2}+\mathrm{CO}_{2}$. The experimental study shows that the reaction between $\mathrm{CO}$ and NO is a first-order reaction. To simplify the model, only the reaction between $\mathrm{CO}$ and $\mathrm{NO}$ on the coke-particle surface is considered, the overall reaction rate can be expressed as follows [37,38]:

$$
R_{N O, C O}=3.68 \times 10^{7} \exp (-108889 / R T) C_{N O} C_{C O}
$$

\subsection{Model Key Parameters and Numerical Methods}

The main parameters involved in the numerical simulation include structural and physical parameters. The structural parameters mainly include the bed shrinkage rate, bed porosity, and solid particle size change. The physical parameters mainly include thermophysical parameters, gas-phase effective diffusion coefficient, and solid-phase heat conduction and radiation. The values and calculation formulas of the parameters are shown in Table 1.

Table 1. Key parameters in the model.

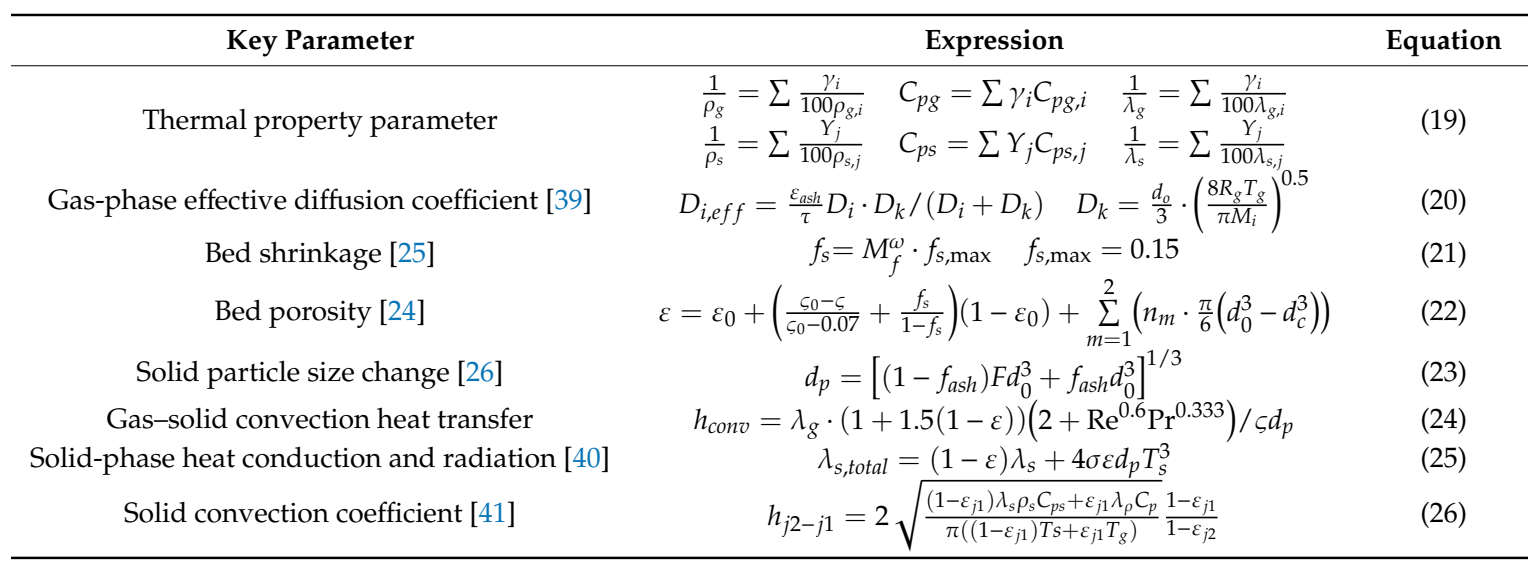

The solution process of flow, heat, and mass transfer problems in this study is based on the C\# programming language. First, the region is discretized, and the rectangular coordinates are established for the sintered layer. The top of the bed layer and the ignition furnace entrance point are the origins, and the mesh is divided. In accordance with the control volume of the node at a certain moment, the mass or energy balance is used to discretize the equation, and the tridiagonal matrix method is used to solve the problem. Considering that the nucleation model based on the kinetic reaction is used in calculating the reaction submodel, the grid space step size is $\Delta x=2.5 \mathrm{~mm}$, and the time step size is $\Delta \mathrm{t}=0.5 \mathrm{~ms}$. In the solution process, the boundary conditions of the inlet are adjusted in accordance with the stage of the trolley.

\subsection{Initial and Boundary Conditions}

Using the developed model and calculation program, the sintering machine of a domestic steel plant is studied. The length of the sintering machine is $88.8 \mathrm{~m}$, the sintering-bed thickness is $680 \mathrm{~mm}$, the running speed is $2.5 \mathrm{~m} \cdot \mathrm{min}^{-1}$, and the flue gas of $1-5 \#$ and $20-23 \#$ bellows is extracted, sending to the 6-16\# (i.e., $23 \mathrm{~m}-67 \mathrm{~m}$ ) bellows for recycling. Figure 2 shows the FGRS process.

The actual production conditions of the sintering machine are set as the initial and boundary conditions of the calculation program. According to the characteristics of the sintering, the boundary conditions of the sintering simulation zone are divided into ignition, insulation and sintering zones.

In the ignition zone $(0-4 \mathrm{~m})$, the ignition temperature is $1150^{\circ} \mathrm{C}$, the ignition fuel is coke oven gas, the suction air temperature is $30^{\circ} \mathrm{C}$, the temperature in the insulation zone $(4-9 \mathrm{~m})$ is $450{ }^{\circ} \mathrm{C}$, and the inhalation component is air. The input gas temperature and gas composition in the cyclic sintering zone $(23-67 \mathrm{~m})$ will be listed in the simulation case. In the other sintering areas, the inhalation component is air and the inhalation air temperature is $30^{\circ} \mathrm{C}$. Table 2 shows the mixing ratio and 
chemical composition of the raw materials. As an important initial condition for the study, the initial temperature of the solid phase is set at $55{ }^{\circ} \mathrm{C}$.

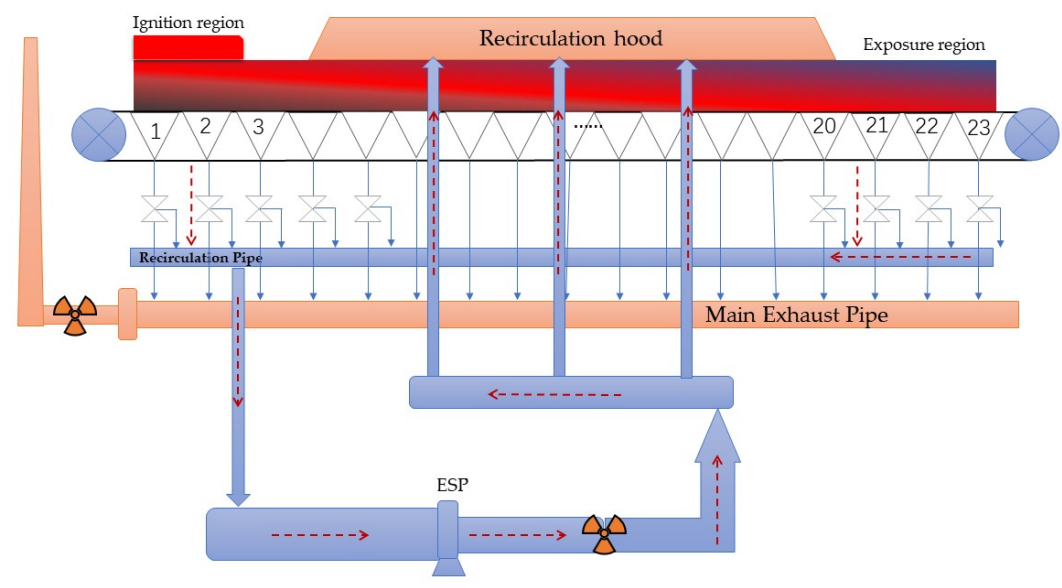

Figure 2. Flue gas recirculation sintering (FGRS).

Table 2. Proportion and chemical composition of raw materials for sintering (wt.\%).

\begin{tabular}{cccccccccc}
\hline Solid Phases & Proportion & $\mathrm{SiO}_{\mathbf{2}}$ & $\mathbf{A l}_{\mathbf{2}} \mathbf{O}_{\mathbf{3}}$ & $\mathbf{C a O}$ & $\mathbf{T F e}$ & $\mathbf{M n O}$ & $\mathbf{N}$ & $\mathbf{S}$ & Moisture \\
\hline Coal char & 3.20 & 5.45 & 3.96 & 0.49 & 0.42 & 0.05 & 0.89 & 0 & 13.62 \\
Iron ore fines & 62.58 & 4.73 & 1.60 & 1.42 & 59.62 & 0.76 & - & 0.24 & 7.95 \\
Returned fines & 26.04 & 4.98 & 1.82 & 8.76 & 58.83 & 1.56 & - & 0.28 & 0.32 \\
Limestone & 4.15 & 1.89 & 0.57 & 52.91 & 0.11 & 1.07 & - & 0.02 & 5.2 \\
Dolomite & 2.56 & 0.74 & 0.38 & 31.47 & 0 & 20.65 & - & 0 & 3.67 \\
Burnt-lime & 1.47 & 1.09 & 0.34 & 52.66 & 0.08 & 0.47 & - & 0.04 & - \\
\hline
\end{tabular}

Moreover, the pressure at the top of the sinter bed is considered to bed $1.0 \mathrm{~atm}$, the radiation heat transfer is neglected, the heat and mass losses at the outlet boundary are not considered, and the gradient of all parameters is set to zero. The mixture temperature is set to be equal to the gas temperature in the sinter bed.

\section{Results and Discussion}

The reliability of the model is verified by comparing the simulated values with the experimental one. First, the effects of circulating gas $\mathrm{O}_{2}$ content, gas temperature and gas supply on NOx emissions in flue gas are studied. Second, the influence of coke parameters on NOx emissions is examined. Finally, the cycle conditions are designed using the CS calculation results, and the energy-saving and emission-reduction effects of the cyclic sintering compared with CS are calculated.

\subsection{Model Verification}

To verify the accuracy of the model used, through the sintering pot experiments, the temperature of the layer from the bottom to the top at $225 \mathrm{~mm}$ and $525 \mathrm{~mm}$ are measured. A portable MRU flue gas analyzer was used to measure the variation of the main components $\left(\mathrm{O}_{2}, \mathrm{CO}_{2}\right.$, and $\left.\mathrm{CO}\right)$ in flue gas, as also described in previous work [23,24]. Using the simulation system, the initial and boundary conditions of the simulation are set to the experimental conditions of the sintering pot. Ignoring the heat and mass losses at the exit boundary, the gradient of all parameters is considered to be zero. The comparison curves between calculated and measured temperatures at typical bed layers of sintering machine are shown in Figure 3. The calculated results of $\mathrm{O}_{2}, \mathrm{CO}_{2}$, and $\mathrm{CO}$ in flue gas and the measured results is shown in Figure 4.

Figure 3 shows that the calculated value of the model is basically consistent with the test value, but the rapid heating points of the measuring points differ from the simulated values. The main 
reason is the positional shift of the thermocouple caused by the melting and pumping action of the bed layer in the sintering pot experiment. Figure 4 shows that after ignition and heat preservation, i.e., from $200 \mathrm{~s}$ to $1400 \mathrm{~s}$, the $\mathrm{O}_{2}, \mathrm{CO}_{2}$, and $\mathrm{CO}$ contents in the sintering state stabilize until the end of sintering, which is also called the steady-state sintering stage. A difference between the calculated and experimental flue gas composition is observed near the endpoint of sintering, and the calculation process is slightly faster than the sintering pot experiment. This finding is probably due to the fact that the coke size assumption in the coke-combustion model is based on the average size of coke within each particle-size range, which differs from the fact.

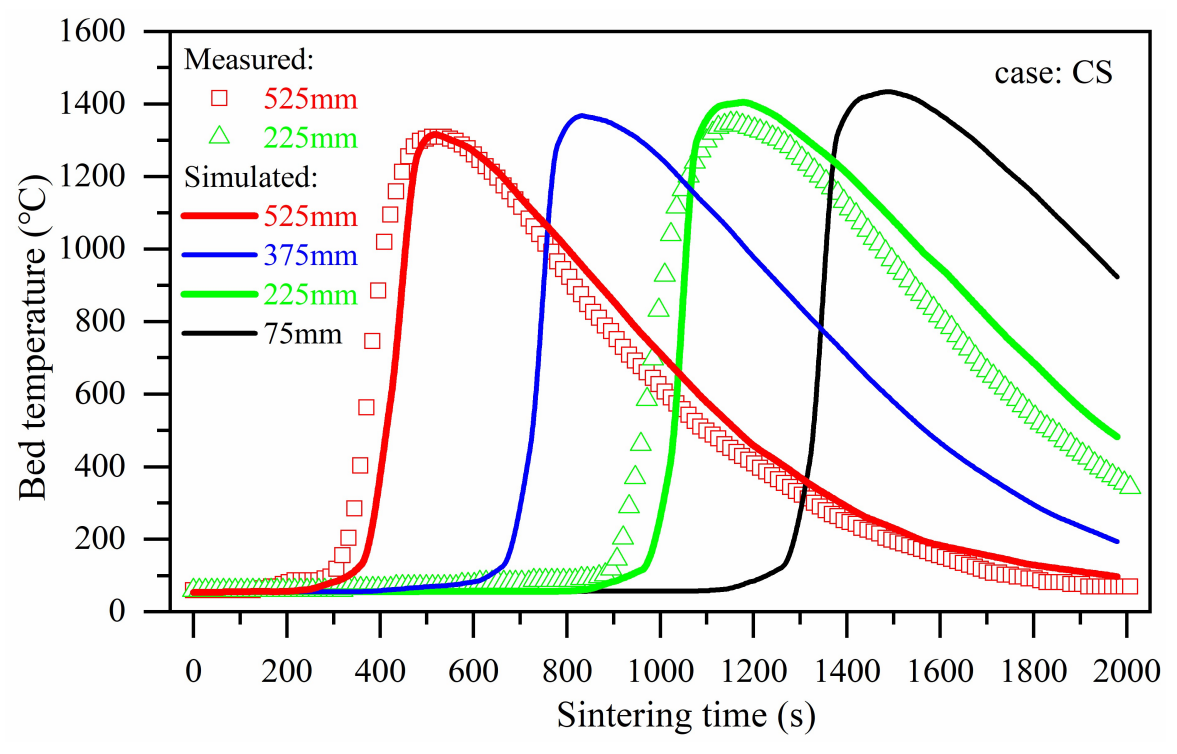

Figure 3. Comparisons between simulated and measured data of bed-layer temperature.

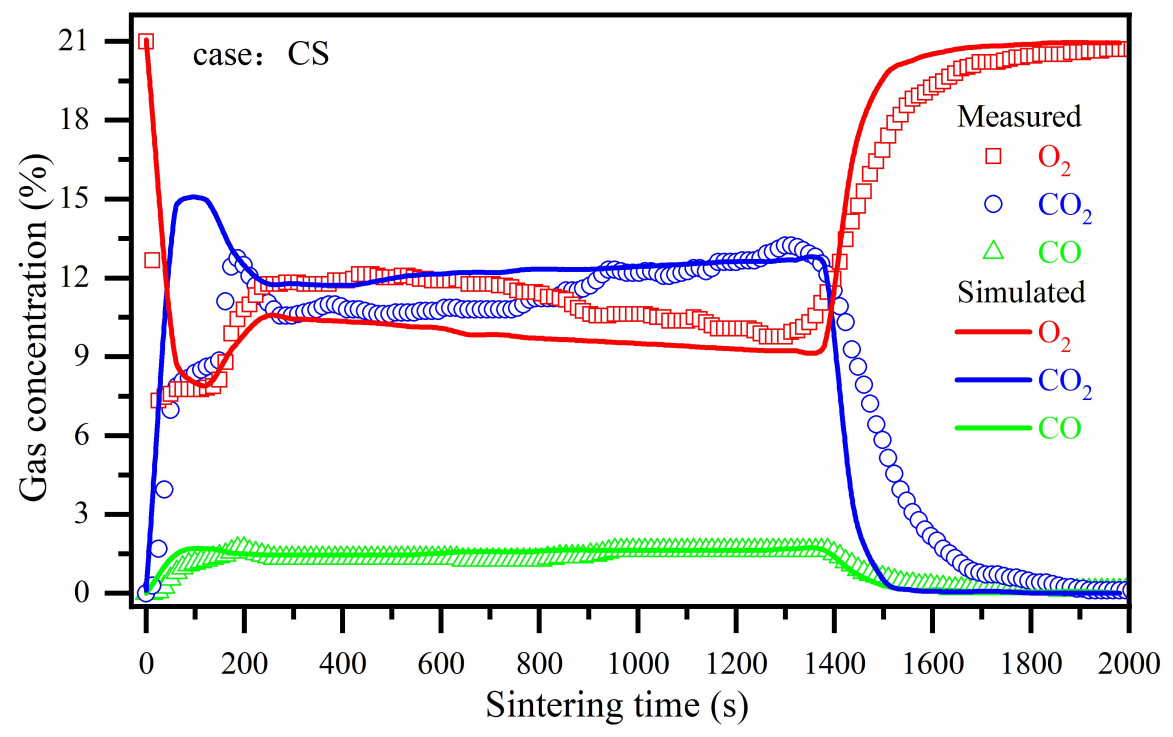

Figure 4. Comparison of simulated and measured values of the main components of flue gas.

Considering that sintering-pot experiment previously does not measure NOx content, to further verify the reliability of the NOx model, the initial and boundary conditions of the simulation system are set to the experimental conditions of Gan et al. [6] The simulated values of NOx formation, reduction, and overall emissions in the FGRS are shown in Figure 5. 


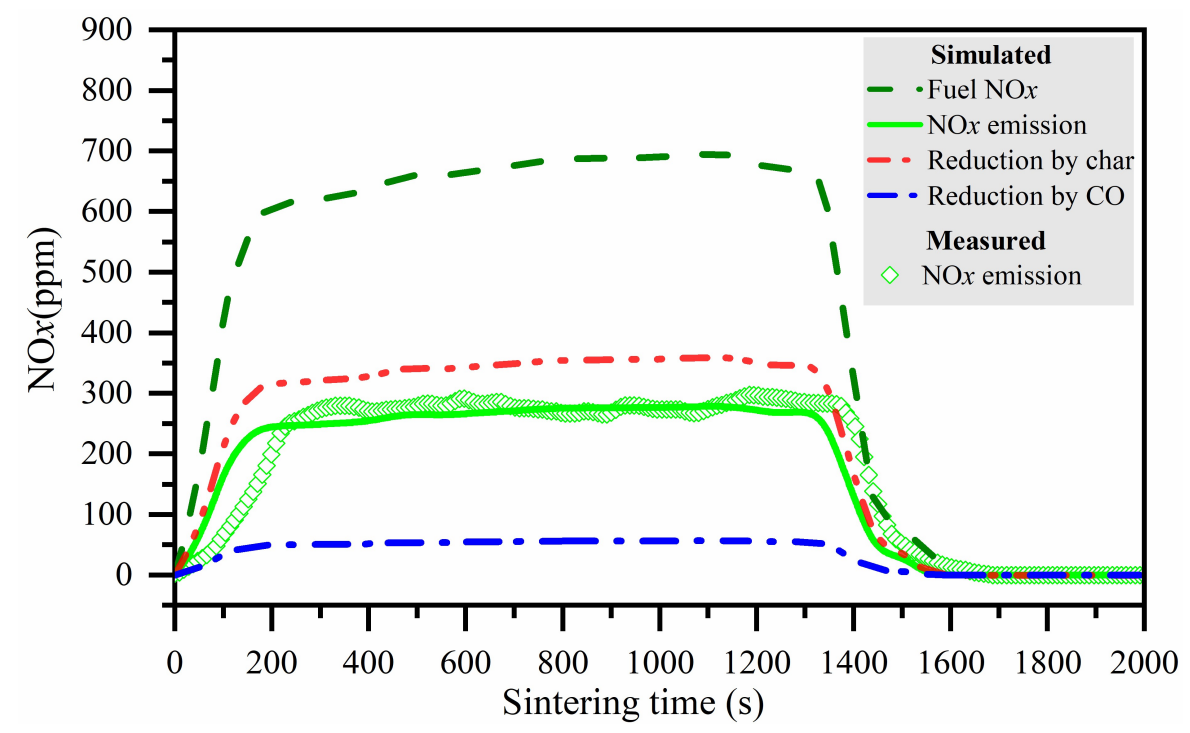

Figure 5. Comparison of NOx simulated and measured results.

The calculation results show that the fuel NOx production in the steady-state sintering stage is about $685 \mathrm{ppm}$, and that the fuel NOx is derived primarily from char-N, in which NOx accounts for more than $90 \%$. This value is related to the nitrogen content of the fuel, bed-layer temperature, and $\mathrm{O}_{2}$ content, which are crucial to the NOx emissions. Thermal NOx is almost negligible because thermal NOx can be produced only when the temperature exceeds $1800 \mathrm{~K}$ and lasts for a certain time. Moreover, Figure 5 shows that the reduction of NOx by coke particles is about $354 \mathrm{ppm}$, accounting for about $51.6 \%$ of the overall formation. The main reason is that the reduction of NOx on the surface of coke particles is relatively strong during NOx diffusion. In addition, the CO generated on the coke surface during combustion partially diffuses into the coke pores and oxidized to form $\mathrm{CO}_{2}$ in the reaction layer, and the other part is reduced with NOx around the coke particles. The amount of NOx reduced by $\mathrm{CO}$ is about $56 \mathrm{ppm}$, so the reduction of NOx by $\mathrm{CO}$ during sintering is obvious.

To compare the calculations and experimental results, the maximum bed-layer temperature (MaxT; ${ }^{\circ} \mathrm{C}$ ), flame front speed (FFS; $\mathrm{mm} / \mathrm{min}$ ), and steady-state flue gas composition values during sintering are summarized in Table 3. During sintering, the melting and crystallization states of the materials are usually characterized by MaxT, and the sintering yield and utilization factor are characterized by FFS. Table 3 shows that the relative errors of the key parameters and flue gas components in sintering are less than $4 \%$, which indicates that the established model can well reflect the actual process.

Table 3. Comparison of simulation and measured results.

\begin{tabular}{|c|c|c|c|c|c|c|c|}
\hline \multirow{2}{*}{ Parameter } & \multirow{2}{*}{$\begin{array}{c}\operatorname{MaxT}\left({ }^{\circ} \mathrm{C}\right) \\
X=225 \mathrm{~mm}\end{array}$} & \multirow{2}{*}{$\begin{array}{c}\operatorname{MaxT}\left({ }^{\circ} \mathrm{C}\right) \\
X=525 \mathrm{~mm}\end{array}$} & \multirow{2}{*}{$\begin{array}{c}\text { FFS } \\
\left(\mathrm{mm} \cdot \mathrm{min}^{-1}\right)\end{array}$} & \multicolumn{4}{|c|}{ SSWGC } \\
\hline & & & & NO $x(\mathrm{ppm})$ & CO (vol.\%) & $\mathrm{CO}_{2}$ (vol.\%) & $\mathrm{O}_{2}(\mathrm{vol} . \%)$ \\
\hline Simulated & 1385.05 & 1295.75 & 25.64 & 274.7 & 1.49 & 11.65 & 10.86 \\
\hline Measured & 1346.35 & 1304.28 & 26.56 & 268.1 & 1.46 & 11.58 & 11.15 \\
\hline Relative error & $2.94 \%$ & $0.67 \%$ & $3.59 \%$ & $2.40 \%$ & $2.01 \%$ & $0.60 \%$ & $2.67 \%$ \\
\hline
\end{tabular}

\subsection{Effect of Circulating Flue Gas Characteristics on NOx Emissions}

In FGRS, part of the flue gas in the sintering bed is reused, which is of great significance for the clean production of sinter because of the recovery of flue gas waste heat, the reduction of energy consumption, and decrease in the overall flue gas and NOx emissions. Given that the physical and chemical changes in flue gas recirculation are affected by the flue gas conditions in the recirculation hood, the effects of the circulating gas $\mathrm{O}_{2}$ content, temperature, and gas supply on NOx emissions in flue gas are studied. Table 4 shows the simulation conditions determined according to the single factor principle. The parameter value range basically covers the practical production process of cyclic 
sintering. Notably, the circulation area is calculated according to the CS simulation results and the designed circulation scheme. The NOx content in the inhaled flue gas in the recirculation hood region is calculated to be $82 \mathrm{ppm}$, and during the single-factor analysis, the inhaled flue gas NOx concentration is considered to be unchanged.

Table 4. Simulation case.

\begin{tabular}{cccc}
\hline Case & $\mathbf{O}_{\mathbf{2}}$ Content (vol.\%) & Temperature $\left({ }^{\circ} \mathbf{C}\right)$ & Gas Supply $\left(\mathbf{N m} \cdot \mathbf{s}^{\mathbf{1}}\right)$ \\
\hline GasO2-* & $17,19,21$ & 200 & 0.6 \\
GasV-* & 19 & 200 & $0.5,0.6,0.7$ \\
GasT-* & 19 & $100,200,300$ & 0.6 \\
\hline
\end{tabular}

\subsubsection{Circulating Gas $\mathrm{O}_{2}$ Content}

The burning rate of coke in the sintered bed layer depends mostly on the $\mathrm{O}_{2}$ content around the coke particles in the combustion zone, so the $\mathrm{O}_{2}$ content of the circulating flue gas has a significant influence on NOx emission in sintering. With the remaining parameters unchanged, the variation curves of bed temperature and $\mathrm{NOx}, \mathrm{O}_{2}$, and $\mathrm{CO}$ contents in flue gas under various cyclic gas $\mathrm{O}_{2}$ contents (17 vol.\%, 19 vol.\%, and 21 vol.\%) are simulated, as shown in Figure 6.

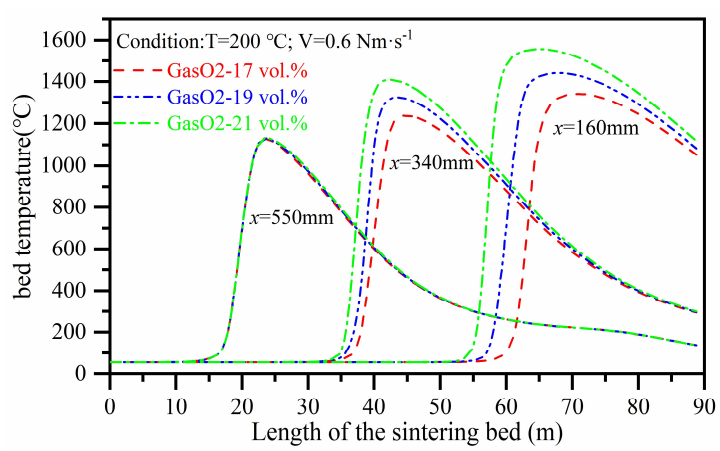

(a) FGRS case for various $\mathrm{O}_{2}$ content

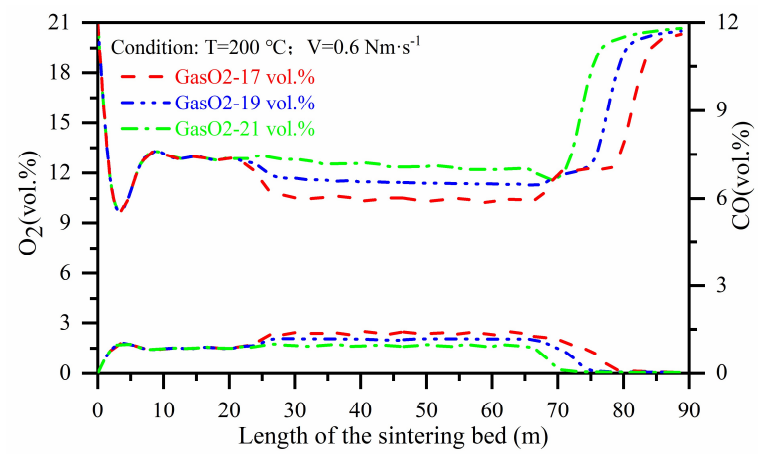

(c) $\mathrm{O}_{2}$ and $\mathrm{CO}$ contents

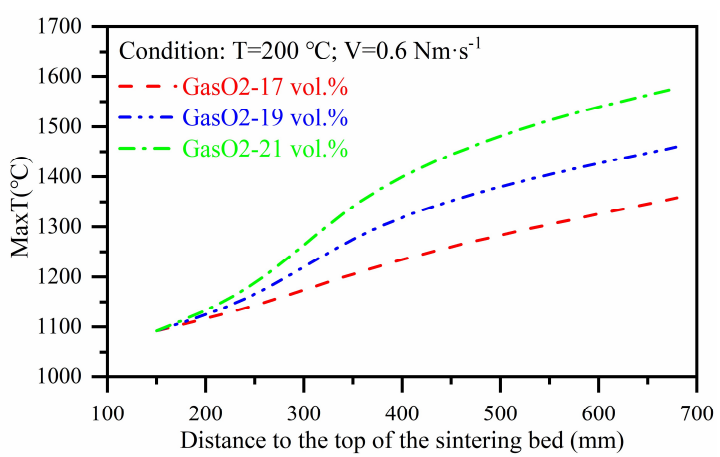

(b) MaxT of different height locations

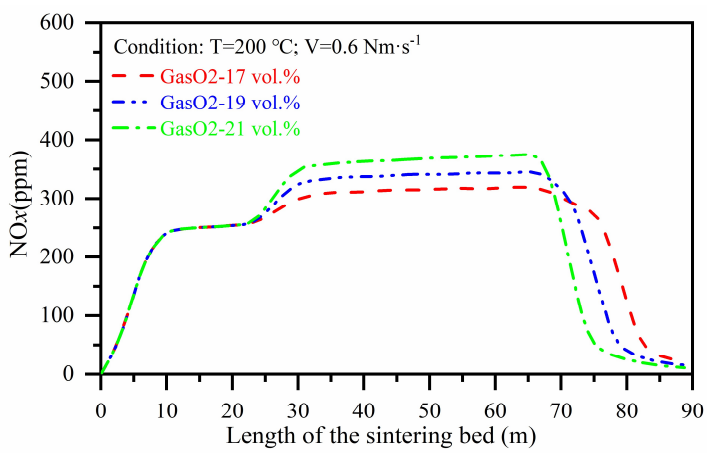

(d) NOx content

Figure 6. Effects of circulating gas $\mathrm{O}_{2}$ content on the $\mathrm{NOx}, \mathrm{CO}$ and $\mathrm{O}_{2}$ contents in flue gas and layer temperature.

According to Figure $6 \mathrm{a}, \mathrm{b}$, with increased $\mathrm{O}_{2}$ content of the circulating flue gas from 17 vol. $\%$ to $21 \mathrm{vol} . \%$, the rapid heating point of the circulating zone is advanced, and less distance to the bottom of the sintering bed layer means faster temperature increase. Considering the heat storage of the layer, a closer MaxT to the bottom of the layer means more obvious. The highest temperature of the layer affects the melting state and is a key factor affecting the sinter quality.

According to Figure $6 c$, with increased circulating flue gas oxygen content from 17 vol. $\%$ to $21 \mathrm{vol} . \%$, the flame-propagation speed increases, the sintering endpoint advances, the CO content 
decreases, and the combustion consumption of $\mathrm{O}_{2}$ increases. At this time, sufficient gas supply of circulating gas is likely to cause overburning. Figure $6 \mathrm{~d}$ shows that the flue gas recirculation zone $(23-67 \mathrm{~m})$ is significantly higher than that in CS. Thus, when the $\mathrm{O}_{2}$ content in the circulating flue gas is $17 \mathrm{vol} \%$, the NOx emission level is about $309 \mathrm{ppm}$, whereas when the $\mathrm{O}_{2}$ content in the circulating flue gas is 21 vol.\%, the NOx content increases to $357 \mathrm{ppm}$ (about 15.5\% higher than that under the $17 \mathrm{vol} . \%$ $\mathrm{O}_{2}$ operating condition). The main reason is that with increased $\mathrm{O}_{2}$ content and coke-combustion efficiency, the char- $\mathrm{N}$ release rate increases and the circulating flue gas $\mathrm{O}_{2}$ content increases to promote the secondary combustion of $\mathrm{CO}$. Moreover, the reducing atmosphere is weakened, resulting in higher NOx emission level. If the $\mathrm{O}_{2}$ content of the circulating flue gas is low, the adsorption of free oxygen by char-N decreases, the rate of NOx formation is reduced, and part of NOx is reductively decomposed through homogeneous and heterogeneous reactions.

\subsubsection{Circulating Gas Temperature}

The flue gas recycling can make full use of flue gas sensible heat, reduce solid fuel consumption, and conducive to environmental protection. However, the location of the selected flue gas is different, the flue gas temperature is very different, the flue gas temperature affects the quality of the sintered ore, when the flue gas temperature is too low, which will affect the fuel combustion inside the sintered layer, increasing the temperature of the circulating gas easily causes the exhaust pipe to be exhausted. the variation curves of bed temperature and $\mathrm{NOx}, \mathrm{O}_{2}$, and $\mathrm{CO}$ contents in flue gas under various cyclic gas temperature $\left(100^{\circ} \mathrm{C}, 200^{\circ} \mathrm{C}\right.$, and $\left.300^{\circ} \mathrm{C}\right)$ are simulated, as shown in Figure 7 .

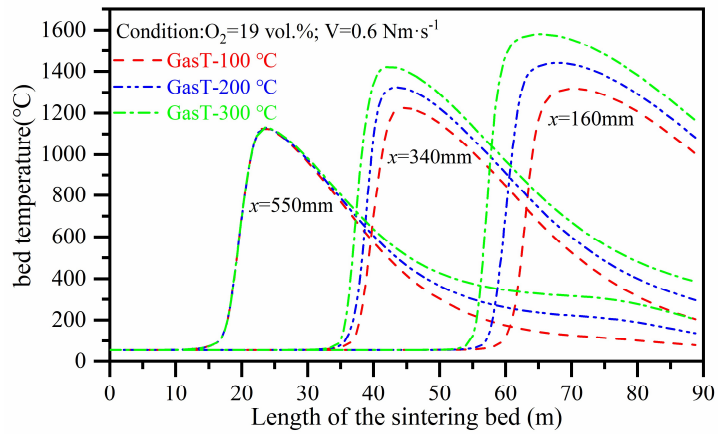

(a) FGRS case for various gas temperature

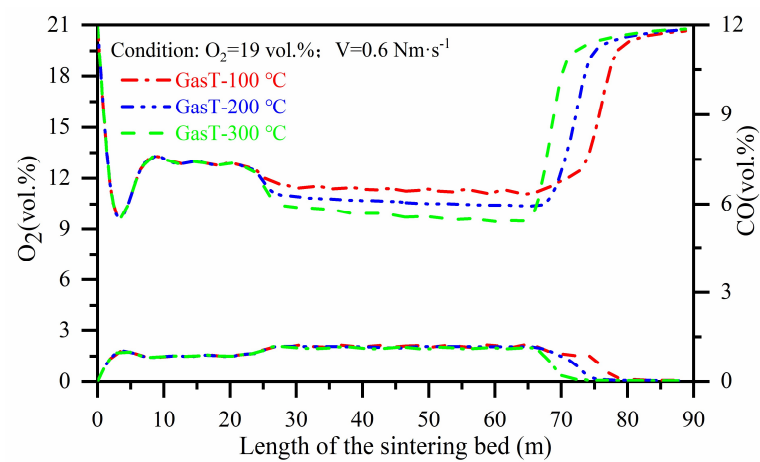

(c) $\mathrm{O}_{2}$ and $\mathrm{CO}$ contents

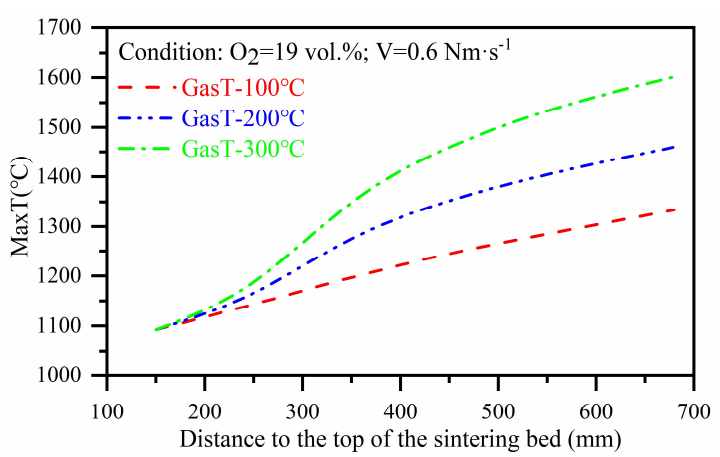

(b) MaxT of different height locations

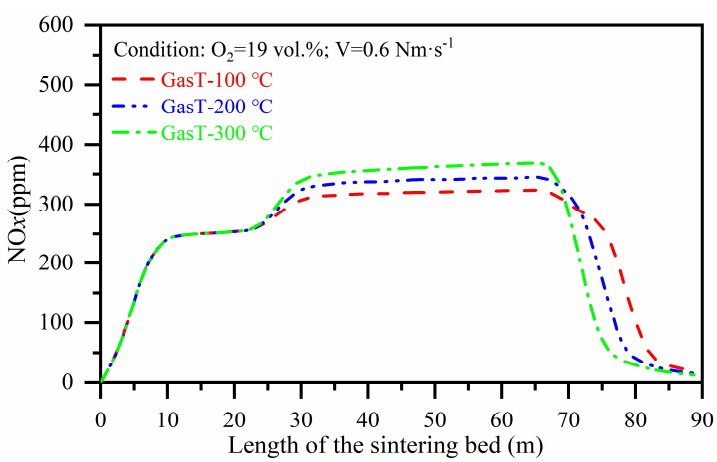

(d) NOx content

Figure 7. Effects of circulating gas temperature on the $\mathrm{NOx}, \mathrm{CO}$ and $\mathrm{O}_{2}$ contents in flue gas and layer temperature.

Figure $7 \mathrm{a}, \mathrm{b}$ show that the rapid heating point of the sintering bed at $\mathrm{x}=550 \mathrm{~mm}$ is almost unaffected because the heating process has been completed before entry into the flue gas recirculation zone. With increased temperature of the circulating flue gas from $100^{\circ} \mathrm{C}$ to $300^{\circ} \mathrm{C}$, the maximum temperature of the bed layer is obviously improved and the heat storage of the bed layer is enhanced, which can 
improve the quality of the sintered ore. Figure $7 \mathrm{c}, \mathrm{d}$ show that the $\mathrm{O}_{2}$ content in the circulation region is lower than that of conventional sintering, which may cause sintering delay. However, increased circulating gas temperature promotes flame-propagation speed, further increasing the consumption of $\mathrm{O}_{2}$, the burning rate of coke, and the release rate of NOx. With increased temperature of circulating flue gas from $100{ }^{\circ} \mathrm{C}$ to $300{ }^{\circ} \mathrm{C}, \mathrm{O}_{2}$ concentration in the circulating area decreases from 12.4 vol. $\%$ to 10.8 vol. \%, and NOx emission increases from 313 ppm to 351 ppm, an increase of about 12.1\%.

Notably, the increase in circulating flue gas temperature promotes coke combustion and NOx production rate. Conversely, the increase in combustion rate increases $\mathrm{O}_{2}$ consumption, and the resulting oxygen-poor atmosphere is conducive to NOx reduction. In addition, the flue gas inhaled in the circulation area contains a certain concentration of $\mathrm{NOx}$, which increases the partial pressure of NOx in the circulation area and promotes the reduction of NOx.

\subsubsection{Circulating Gas Supply}

Sintering may actually be induced by the excessive wet belt moving down, so the flame front approaches the bottom of the layer. The thinner wet belt leads to larger porosity and particle size of the sintered layer; thus, gas flow capacity is enhanced. Consequently, the gas volume through the sintered layer changes. Therefore, the amount of circulating gas supply is closely related to the sintering process and NOx emission levels. The curves of the sintering bed temperature and the NOx, $\mathrm{O}_{2}$, and $\mathrm{CO}$ contents in flue gas under various circulating gas velocities $\left(0.5,0.6\right.$, and $\left.0.7 \mathrm{Nm} \cdot \mathrm{s}^{-1}\right)$ are simulated, as shown in Figure 8.

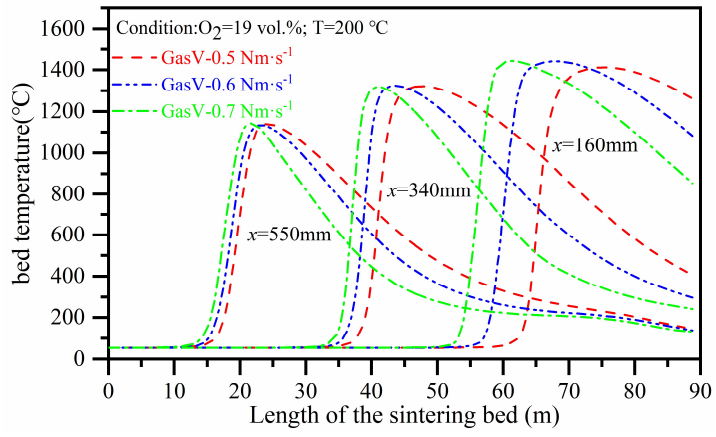

(a) FGRS case for various gas supply

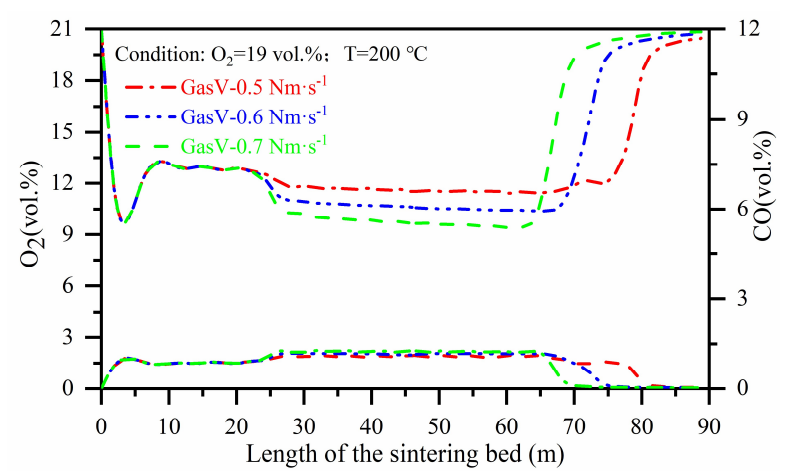

(c) $\mathrm{O}_{2}$ and $\mathrm{CO}$ contents

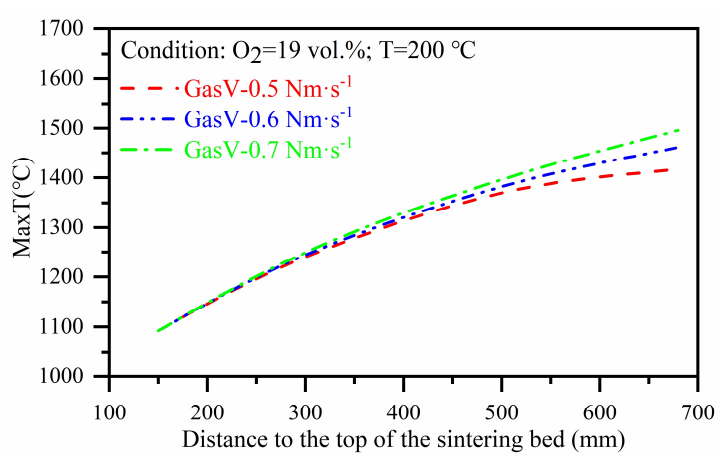

(b) MaxT of different height locations

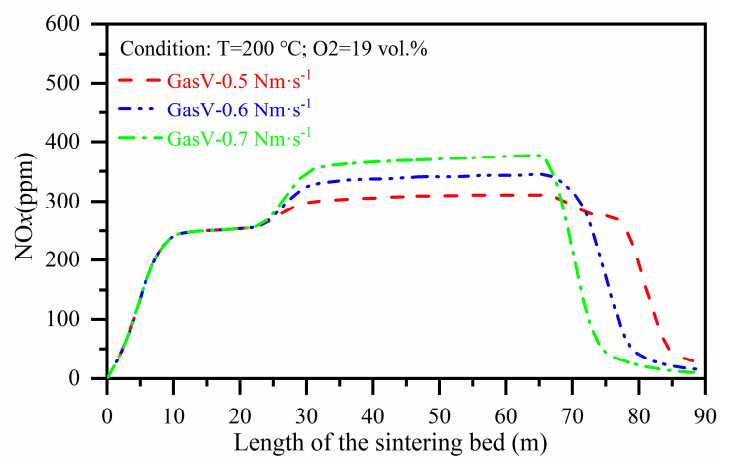

(d) NOx content

Figure 8. Effects of circulating gas supply on the $\mathrm{NOx}, \mathrm{CO}$, and $\mathrm{O}_{2}$ contents in flue gas and layer temperature.

Figure 8a,b shows the significant influence of circulating flue gas supply on bed temperature and NOx emission. With increased circulating flue gas supply, the rapid heating point is advanced, and less distance to the bottom of the bed means earlier rapid heating point. In other words, the gas supply can improve the combustion efficiency of coke; however, in the actual production process, the increase 
in gas supply increases the $\mathrm{O}_{2}$ flux and combustion efficiency. At the same time, the increase in gas supply enhances the convective cooling effect of the sinter layer and increases the heat loss caused by combustion.

Figure $8 c$,d shows that with increased circulating-gas supply, the $\mathrm{O}_{2}$ content in the flue gas recirculation area decreases from 11.9 vol. $\%$ to 10.3 vol. $\%$, the NOx content increases from $303 \mathrm{ppm}$ to $358 \mathrm{ppm}$, the emission level increases by $18.2 \%$, the flame-propagation speed is accelerated, the sintering endpoint is advanced, and the NOx content decreases rapidly. Evidently, with increased circulating-gas supply, the coke combustion efficiency increases and the char- $\mathrm{N}$ release rate increases. At the same time, the consumption of $\mathrm{O}_{2}$ increases, the $\mathrm{O}_{2}$ content in circulating flue gas decreases, the content of $\mathrm{CO}$ increases, and the reducing atmosphere is enhanced, which are conducive to NOx reduction and decreased NOx emissions. In addition, the high material layer temperature is beneficial to the formation of a liquid phase and promotes the transformation of $\mathrm{NOx}$ to $\mathrm{N}_{2}$.

\subsection{Effect of Coke Particle Size and Coke Rate on NOx Emissions}

Different coke particle sizes cause differences in porosity and specific surface area, thereby affecting the concentration of gas phase components and gas-flow resistance in the pores of coke particles. Coke provides the energy required for sintering, and the coke rate affects the decomposition of the flux and the formation of the liquid phase. The effects of coke particle size and content on flue gas recirculation and overall NOx emissions are discussed below. Table 5 shows the simulated conditions determined according to the single factor principle. During analysis, we consider that the inhaled NOx content in the flue gas circulation area does not change.

Table 5. Simulation case.

\begin{tabular}{cccccc}
\hline Case & Coke Size $(\mathbf{m m})$ & Coke Rate $(\%)$ & $\mathbf{O}_{\mathbf{2}}$ Content $($ vol.\%) & Temperature $\left({ }^{\circ} \mathbf{C}\right)$ & Gas Supply $\left(\mathbf{N m} \cdot \mathbf{s}^{-\mathbf{1}}\right)$ \\
\hline size- $^{*}$ & $1.5,1.7,1.9$ & 3.2 & 19 & 200 & 0.6 \\
rate- & 1.7 & $3.0,3.2,3.4$ & 19 & 200 & 0.6 \\
\hline
\end{tabular}

\subsubsection{Coke Particle Size}

With decreased particle size of a single coke, the effective reaction area of the combustion interface decreases, and the combustion efficiency remarkably decreases. However, for coke combustion per unit mass, the refinement of coke particles can increase the total surface area, thereby increasing the combustion rate and promoting full contact between NOx and the coke surface. The effects of coke particle with equivalent diameters of $1.5,1.7$, and $1.9 \mathrm{~mm}$ on $\mathrm{NOx}, \mathrm{O}_{2}$, and $\mathrm{CO}$ emissions in flue gas and MaxT are simulated, as shown in Figure 9.

Figure $9 a, b$ shows that with the refinement of coke particles, the number of coke particles per unit mass increases, the comprehensive combustion rate increases, and MaxT increases. Moreover, less distance to the bottom of the bed means a thicker high temperature zone and increased sinter strength. At the same time, $\mathrm{O}_{2}$ consumption increases, $\mathrm{O}_{2}$ content decreases from $11.3 \%$ to $9.7 \%$, the inhibition of coke combustion is enhanced, the reducing atmosphere is enhanced, and the finished product rate is reduced. Thus, the $\mathrm{O}_{2}$ content in the circulating hood should be kept close to air as much as possible.

Figure 9c,d shows that with decreased coke particle size, NOx emission increases from $318 \mathrm{ppm}$ to $360 \mathrm{ppm}$, an increase of about $13.2 \%$. When the coke particle size is $1.5 \mathrm{~mm}$, the comprehensive coke combustion rate increases, and the char- $\mathrm{N}$ release rate in the flue gas recirculation zone increases. Conversely, the coke surface area per unit mass increases such that the coke particles can make full contact with NOx and thus promote the reduction of NOx by coke particle and CO. At this time, the reduction rate is about $61.4 \%$, which is conducive to reducing NOx emissions. However, in the actual production process, considering the control of production costs, achieving superfine coke is impossible. At present, the equivalent particle size of coke for sintering is controlled at $1.5-2.0 \mathrm{~mm}$. Screening of coke with smaller particle size is beneficial to the actual production process of flue gas recirculation, which is beneficial to the reduction of NOx emissions. 


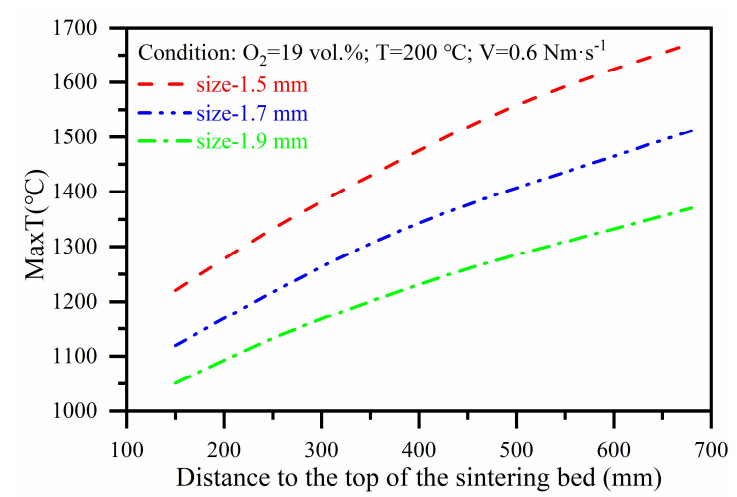

(a) MaxT of different height locations

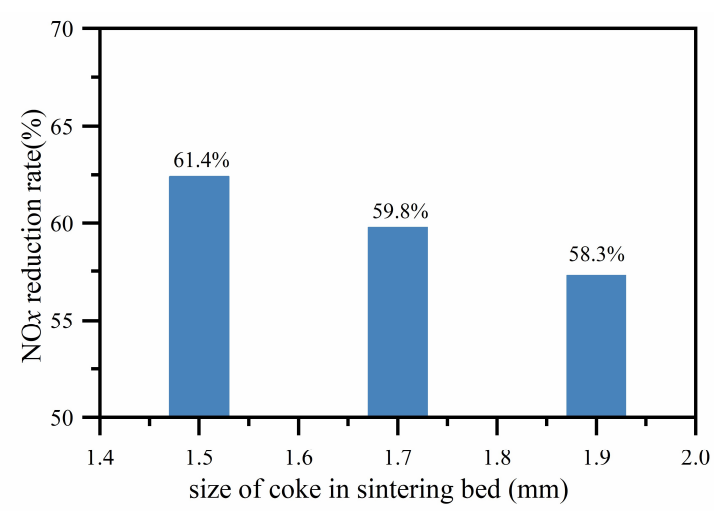

(c) Effect of coke size on NOx Reduction rate

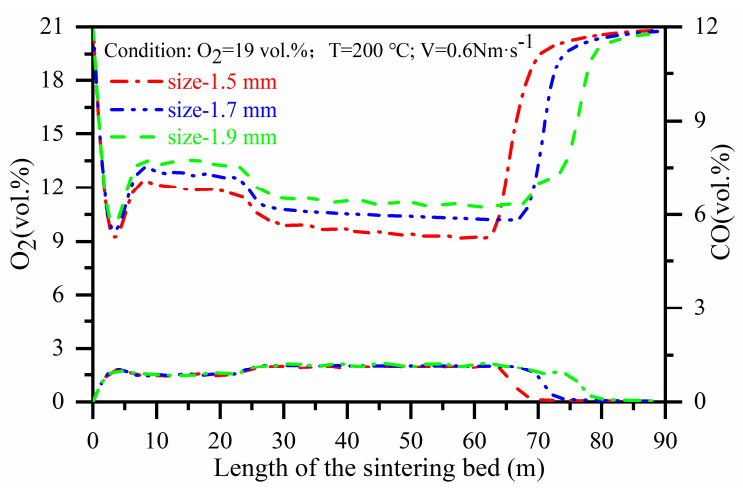

(b) $\mathrm{O}_{2}$ and $\mathrm{CO}$ contents

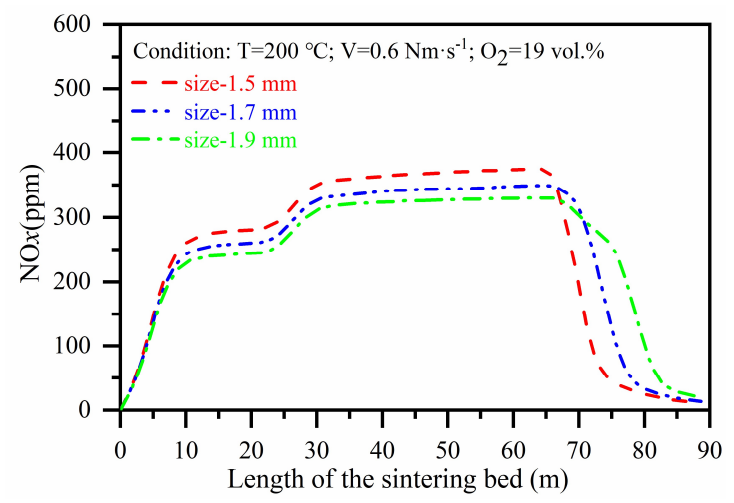

(d) Effect of coke size on NOx emissions

Figure 9. Effects of coke size on $\mathrm{NOx}, \mathrm{CO}$, and $\mathrm{O}_{2}$ contents in flue gas and MaxT.

\subsubsection{Coke Rate}

As a sintering fuel, coke content promotes flux decomposition and sintering liquid-phase formation. Fuel carbon and fuel nitrogen are the main sources of NOx release during sintering. To study the effects of coke rate on the temperature of the sinter bed layer and NOx emissions, the curves of NOx, $\mathrm{O}_{2}$, and $\mathrm{CO}$ contents in flue gas and MaxT (Maximum temperature) are simulated under the conditions of various coke contents $(3.0 \%, 3.2 \%$, and $3.4 \%)$, as shown in Figure 10 .

Figure $10 \mathrm{a}, \mathrm{b}$ shows that increased coke content increases the average temperature of the layer, and less distance to the bottom of the sintered bed layer means a higher MaxT. Consequently, the quality of the sintered ore is improved. With increased coke content, more heat is generated, the flame-propagation speed increases, and the vertical sintering speed increases, so the sintering endpoint is advanced. The increase in solid fuel increases the $\mathrm{O}_{2}$ consumption, decreases the $\mathrm{O}_{2}$ content in the circulation region from $11.5 \%$ to $9.9 \%$, and enhances the reducing atmosphere.

Figure 10c,d shows that with increased coke rate, the NOx content increases from $306 \mathrm{ppm}$ to $369 \mathrm{ppm}$, which is an increase of about $20.6 \%$, and the reduction rate is $62.1 \%$. The oxidation reaction of coke particles and $\mathrm{O}_{2}$ and the reduction of coke particles and NOx are all strengthened, i.e., the amount of NOx formed and reduced increases with increased coke content. At the same time, the increase in coke content can increase the coke burning rate and increase the vertical sintering speed such that the sintering endpoint is reached in advance and the NOx content rapidly drops earlier. In summary, increased coke content means increased char-N, NOx emissions, and reduction rate of coke particle and $\mathrm{CO}$. 


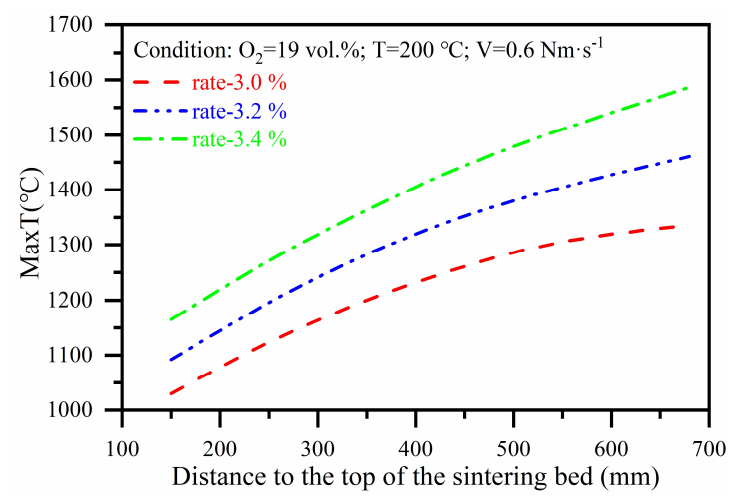

(a) MaxT of different height locations

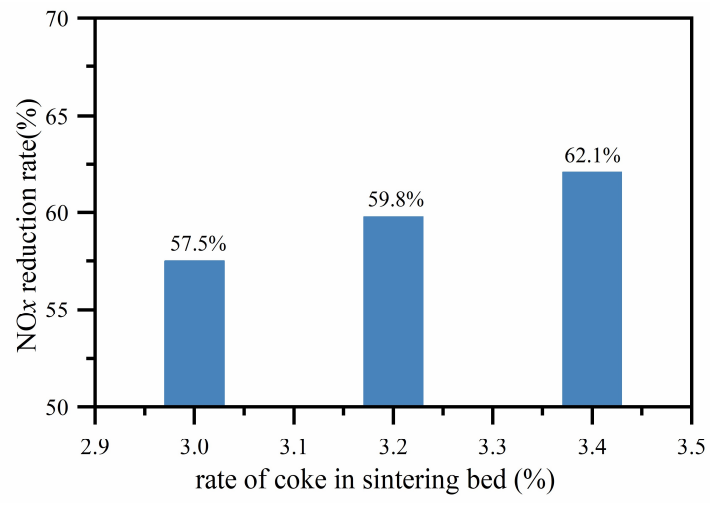

(c) Effect of coke rate on NOx reduction rate

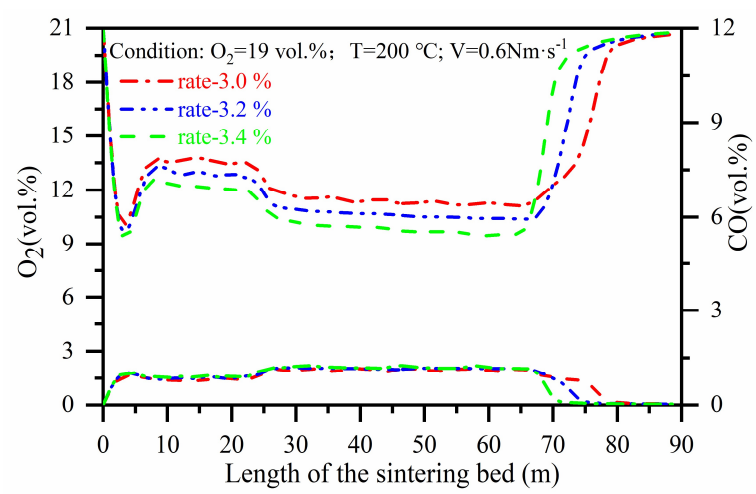

(b) $\mathrm{O}_{2}$ and $\mathrm{CO}$ contents

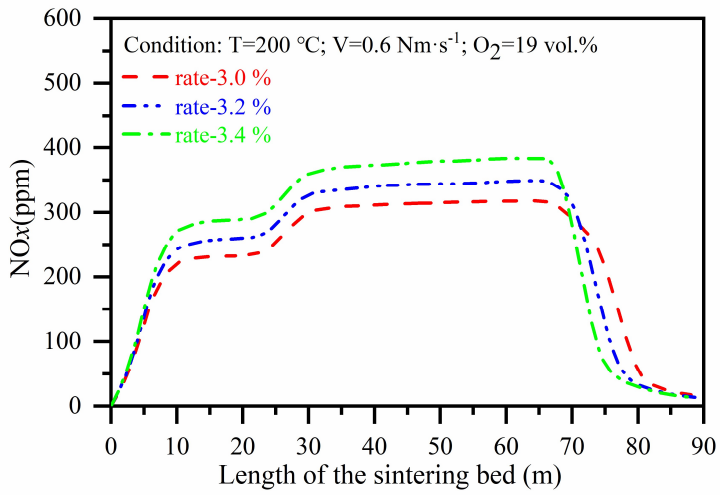

(d) Effect of coke rate on NOx emissions

Figure 10. Effect of coke rate on $\mathrm{NOx}, \mathrm{CO}, \mathrm{O}_{2}$ content in flue gas and MaxT (Maximum temperature).

\subsection{Analysis of Energy-Saving and Emission-Reduction Features of FGRS}

Conventional sintering has the problems of difficulty in utilizing waste heat and high cost of flue gas treatment. From the perspective of economy and technology, FGRS is advantageous over CS because FGRS can effectively use the flue gas heat to replace the chemical heat of solid fuel. Consequently, the amount of solid fuel, Char-N incorporation, and the amount of flue gas treatment are reduced. The efficiency of denitrification treatment is also improved, yielding significant economic benefits. According to the simulation results of CS, according to the cycle sintering design (i.e., the flue gas of the \#1-\#5 and \#20 \#23 bellows is sent to the \#6-\#16 bellows), the air leakage rate is calculated at $30 \%$. Then, the flue gas composition and state of circulation area are calculated based on the exhaust emission law, as shown in Table 6.

Table 6. Simulation case.

\begin{tabular}{cccccc}
\hline Case & $\mathbf{O}_{\mathbf{2}}$ Content (vol. $\left.\%\right)$ & Temperature $\left({ }^{\circ} \mathbf{C}\right)$ & Gas Supply $\left(\mathbf{N m} \cdot \mathbf{s}^{-\mathbf{1}}\right)$ & Coke Rate $(\%)$ & NOx $(\mathbf{p p m})$ \\
\hline CS & 21 & 30 & 0.437 & 3.2 & 0 \\
FGRS & 18.06 & 226 & 0.5465 & 3.08 & 104 \\
\hline
\end{tabular}

\subsubsection{Comparison of Flue Gas Recirculation Sintering and Conventional Sintering}

We take a domestic $650 \mathrm{t} / \mathrm{h}$ sintering machine as the research object for flue gas circulation sintering. Given that the sensible heat and latent heat of the circulating flue gas are fully utilized, the coke content in sintering raw materials can be reduced appropriately. According to the simulation results, with decreased coke rate of sintering raw material from $3.2 \%$ to $3.08 \%$ in flue gas recirculation, the sintering endpoint temperature (defined in this study as the temperature at each thickness of the point layer $x=30 \mathrm{~mm}$ ) is basically the same as the CS endpoint temperature. At this time, 
the temperature of the material layer and the $\mathrm{O}_{2}, \mathrm{CO}$, and NOx contents in the flue gas of cyclic sintering and CS are nearly unchanged. The content simulation results are shown in Figure 11.

Figure 11a shows that when the conventionally sintered coke content is $3.2 \%$, the maximum temperature of each bed layer is the same as that of the recirculated sintered coke content of $3.08 \%$. Outside the flue gas recirculation zone, the rapid heating point of the bed layer is slightly delayed because the coke content in this area is lower than that in CS, and the generated heat is slightly lower than that in CS. In the flue gas recirculation area, given the utilization of flue gas waste heat, less distance to the bottom of the layer means faster temperature increase in the layer, increased vertical sintering speed, and increased sinter output per unit time.

Figure $11 \mathrm{~b}$ shows that decreased coke content before recirculated flue gas entry into the circulating region means lower char-N content and release rate of NOx lower. When entering the flue gas recirculation region, the $\mathrm{O}_{2}$ content in the flue gas is lower, the release rate of char- $\mathrm{N}$ is faster, and the inhalation flue gas contains some NOx. Thus, the NOx emission level in the circulating sintering zone is high.

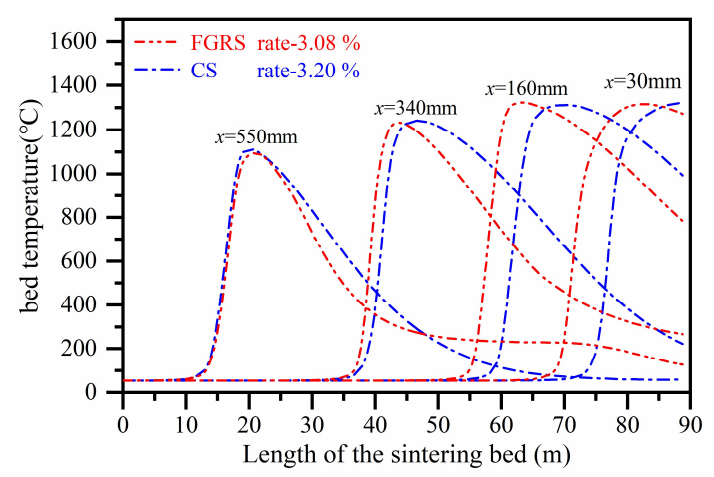

(a) Sinter bed temperature of FGRS and CS cases

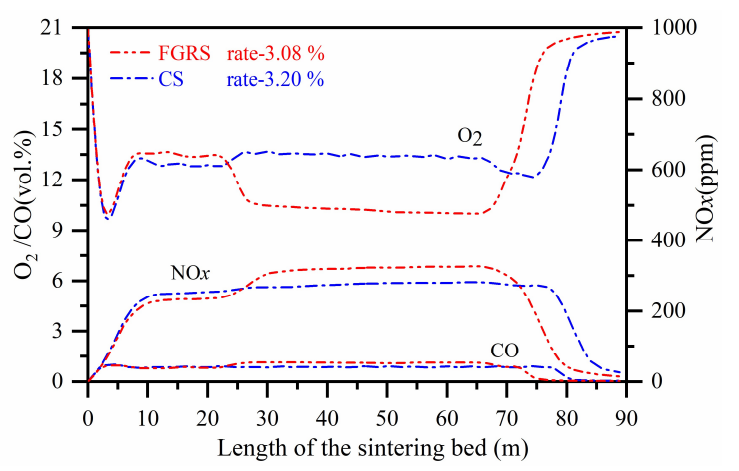

(b) $\mathrm{O}_{2}, \mathrm{CO}$ and NOx contents

Figure 11. Comparison of sinter bed temperature and flue gas composition of FGRS and CS cases.

\subsubsection{Energy-Saving and Emission-Reduction Feature Analyses}

(1) Coke energy saving: For FGRS, the sensible heat and latent heat of the circulating flue gas can be fully utilized. Simulation results show that the coke content of the sintering raw material under the flue gas circulation sintering condition is reduced from $3.2 \%$ to $3.08 \%$, i.e., $3.75 \%$ coke consumption is saved. Thus, the new process can be considered to appropriately reduce the solid fuel consumption, and its value is $1.2 \mathrm{~kg} / \mathrm{t}$ sinter. If the sintering machine capacity is calculated according to the output of $650 \mathrm{t} / \mathrm{h}$ and an annual running time of $8000 \mathrm{~h}$, the annual savings of coke powder is $6.24 \times 10^{6} \mathrm{~kg}$, equivalent to 6061.5 tons of standard coal (conversion coefficient of 0.9714$)$.

(2) NOx emission reduction: In the new process design, flue gas in the \#6-\#16 bellows is used as the flue gas used for circulation according to the air leakage rate of $30 \%$. The total amount of CS flue gas is $108.8 \mathrm{Nm}^{3} \cdot \mathrm{h}^{-1}$, and the total flue gas of circulation sintering $122.4 \mathrm{Nm}^{3} \cdot \mathrm{h}^{-1}$, in which the circulating flue gas is $37.1 \mathrm{Nm}^{3} \cdot \mathrm{h}^{-1}$, i.e., the flue gas treatment volume is reduced by $21.64 \%$. The calculation results of conventional and cyclic sintering flue gas volume and simulation results of NOx content in flue gas reveal that the new sinter production unit can reduce NOx emissions by $23.59 \%$.

(3) Capacity increase: Simulation results show that the endpoint of the FGRS is about $5 \mathrm{~m}$ ahead, i.e., the sintering cycle time is shortened. Thus, the sintering capacity can be increased by about $5.56 \%$ without changing the existing sintering equipment. 


\section{Conclusions}

(1) To study the flue gas recirculation, a relatively comprehensive one-dimensional unsteady mathematical model is proposed, which includes most of the main reactions during sintering and emission models of pollutants $\mathrm{NOx}$ and $\mathrm{SO}_{2}$. On this basis, the effects of flue gas characteristics and coke parameters on sinter-bed temperature, as well as the $\mathrm{NOx}, \mathrm{O}_{2}$, and $\mathrm{CO}$ contents in flue gas, are investigated. Compared with CS, the energy-saving and emission-reduction effects of flue gas recycling are discussed.

(2) With decreased $\mathrm{O}_{2}$ content in circulating gas, coke combustion is inhibited, MaxT is significantly reduced, sintering is delayed, and NOx emission is significantly reduced. With increased circulating gas temperature, the high-temperature zone thickness increases, MaxT significantly increases, and $\mathrm{O}_{2}$ consumption increases. Consequently, the reducing atmosphere is enhanced and NOx emission increases. With increased circulating gas supply, flame-propagation speed increases, MaxT remains unchanged, $\mathrm{O}_{2}$ consumption increases, and $\mathrm{NOx}$ concentration in flue gas increases. Thus, coke-combustion efficiency increases, $\mathrm{O}_{2}$ consumption increases, char- $\mathrm{N}$ release rate increases, and $\mathrm{O}_{2}$ content in flue gas decreases. Moreover, the reducing atmosphere is enhanced and the NOx reduction by coke particle and CO is promoted, which are favorable for NOx emission reduction.

(3) Changing the coke particle size and rate during flue gas recycling has an important effect on the bed layer temperature and NOx emissions. However, smaller coke particle size and increased coke rate result in significantly increased MaxT, increased $\mathrm{O}_{2}$ consumption, sufficient contact of NOx with the coke surface, and increased reducing atmosphere. Consequently, the NOx reduction rate increases.

(4) On the basis of the research object, the designed flue gas recirculation can save $3.75 \%$ of coke consumption, i.e., $1.2 \mathrm{~kg}$ solid fuel consumption per ton sinter can be reduced, the flue gas treatment capacity can decrease by $21.64 \%$, and the sinter production unit can reduce NOx emission by $23.59 \%$. Sintering capacity also increases by about $5.56 \%$ without changing the existing sintering equipment.

Author Contributions: Conceptualization, J.H. and G.L.; methodology, J.H., G.L. and Z.W.; project administration, X.L.; software, J.H. and G.L.; supervision, G.L., S.Z., Z.W. and J.L.; validation, J.H.; writing-review and editing, G.L., Z.W.

Funding: This work was financially supported by National Key R\&D Program of China: [Grant Number No. 2017YFC0210304].

Conflicts of Interest: The authors declare no conflict of interest.

\section{Nomenclature}

\begin{tabular}{|c|c|}
\hline Assa & the specific surface area of the solid phase particles, $\mathrm{m}^{2} \cdot \mathrm{m}^{-3}$ \\
\hline $\mathrm{Cps}, \mathrm{Cpg}$ & specific heat capacity of solid and gas phase, $\mathrm{J} \cdot \mathrm{kg}^{-1} \mathrm{~K}^{-1}$ \\
\hline$C_{\mathrm{NO}}, \mathrm{C}_{\mathrm{CO}}$ & molar concentrations of $\mathrm{NO}$ and $\mathrm{CO}, \mathrm{mol} \cdot \mathrm{m}^{-3}$ \\
\hline$D_{i, \text { eff }}$ & effective gas diffusion coefficient, $\mathrm{m}^{2} \cdot \mathrm{s}^{-1}$ \\
\hline$d_{p}$ & equivalent particle size of solid phase, $m$ \\
\hline$h_{\text {conv }}$ & convection coefficient, $\mathrm{W} \cdot \mathrm{m}^{-2} \mathrm{~K}^{-1}$ \\
\hline$h_{j 1, j 2}$ & convection among solid phases, $\mathrm{W} \cdot \mathrm{m}^{-2} \mathrm{~K}^{-1}$ \\
\hline$\Delta H$ & chemical reaction heat, ${\mathrm{kJ} \cdot \mathrm{kg}^{-1}}^{-1}$ \\
\hline$K_{e q}$ & action equilibrium constant, - \\
\hline$k_{\mathrm{NO}, \mathrm{c}}, k_{\mathrm{NO}, \mathrm{CO}}$ & reaction rate constant, $\mathrm{kg} \cdot \mathrm{cm}^{-2} \mathrm{~s}^{-1} \mathrm{~Pa}^{-1}$ \\
\hline$m_{0}, m_{c}$ & mass density of the initial particle and un- \\
\hline$I_{N O}, M_{N}$ & nolecular weights of $\mathrm{NO}$ and $\mathrm{N}, \mathrm{kg} \cdot \mathrm{kmol}^{-}$ \\
\hline NO & artial pressure of $\mathrm{NO}$ in the air, $\mathrm{Pa}$ \\
\hline $\mathrm{R}_{\mathrm{NO}, f}$ & elease rate of fuel NOx, $\mathrm{kg} \cdot \mathrm{s}^{-1} \mathrm{~m}^{-3}$ \\
\hline
\end{tabular}




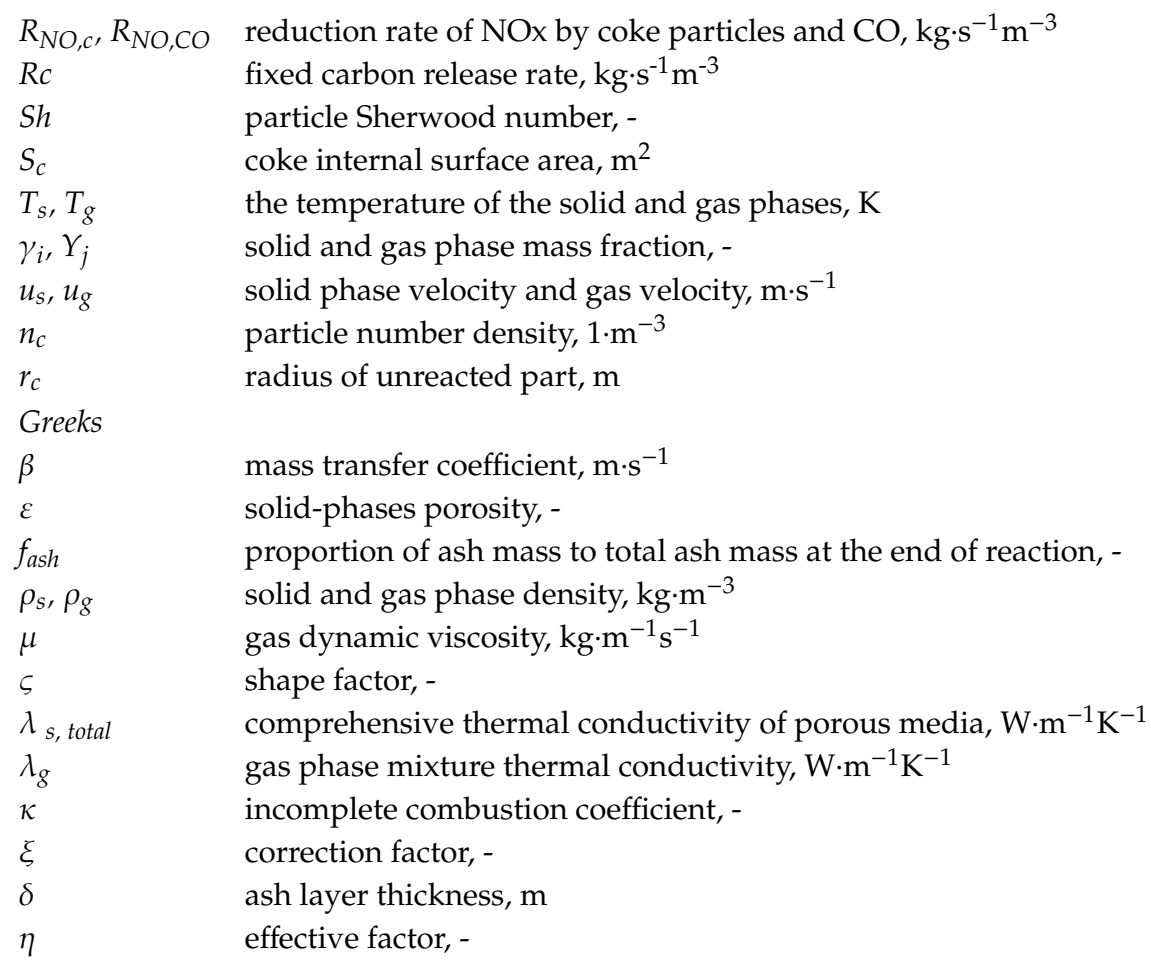

\section{References}

1. Chen, Y.-G.; Guo, Z.-C.; Wang, Z.; Feng, G.-S. NOx reduction in the sintering process. Int. J. Miner. Met. Mater. 2009, 16, 143-148. [CrossRef]

2. Goemans, M.; Clarysse, P.; Joannès, J.; De Clercq, P.; Lenaerts, S.; Matthys, K.; Boels, K. Catalytic NOx reduction with simultaneous dioxin and furan oxidation. Chemosphere 2003, 50, 489-497. [CrossRef]

3. Liu, C.; Zhang, Y.-Z.; Zhao, K.; Xing, H.-W.; Kang, Y. Modified biomass fuel instead of coke for iron ore sintering. Ironmak. Steelmak. 2018, 1-7. [CrossRef]

4. Jha, G.; Soren, S. Study on applicability of biomass in iron ore sintering process. Renew. Sustain. Energy Rev. 2017, 80, 399-407. [CrossRef]

5. Gan, M.; Fan, X.; Ji, Z.; Jiang, T. Application of biomass fuel in iron ore sintering: Influencing mechanism and emission reduction. Ironmak. Steelmak. 2015, 42, 27-33. [CrossRef]

6. Gan, M.; Fan, X.; Ji, Z.; Chen, X.; Jiang, T. Effect of distribution of biomass fuel in granules on iron ore sintering and NOx emission. Ironmak. Steelmak. 2014, 41, 430-434. [CrossRef]

7. Cheng, Z.; Wang, J.; Wei, S.; Guo, Z.; Yang, J.; Wang, Q. Optimization of gaseous fuel injection for saving energy consumption and improving imbalance of heat distribution in iron ore sintering. Appl. Energy 2017, 207, 230-242. [CrossRef]

8. Zhou, H.; Cheng, M.; Zhou, M.; Liu, Z.; Liu, R.; Cen, K. Influence of sintering parameters of different sintering layers on NOx emission in iron ore sintering process. Appl. Therm. Eng. 2016, 94, 786-798. [CrossRef]

9. Zhou, H.; Liu, Z.; Cheng, M.; Zhou, M.; Liu, R. Influence of Coke Combustion on NOx Emission during Iron Ore Sintering. Energy Fuels 2015, 29, 974-984. [CrossRef]

10. Gan, M.; Fan, X.; Chen, X.; Ji, Z.; Lv, W.; Wang, Y.; Yu, Z.; Jiang, T. Reduction of Pollutant Emission in Iron Ore Sintering Process by Applying Biomass Fuels. ISIJ Int. 2012, 52, 1574-1578. [CrossRef]

11. Chen, Y.; Guo, Z.; Wang, Z. Influence of $\mathrm{CeO}_{2}$ on $\mathrm{NOx}$ emission during iron ore sintering. Fuel Process. Technol. 2009, 90, 933-938. [CrossRef]

12. Kasai, E.; Wu, S.; Sugiyama, T.; Inaba, S.; Omori, Y. Combustion Rate and NO Emission during Combustion of Coke Granules in Packed Beds. Tetsu Hagane 1992, 78, 1005-1012. [CrossRef]

13. Chen, Y.-G.; Guo, Z.-C.; Wang, Z. Application of Modified Coke to NOx Reduction with Recycling Flue Gas during Iron Ore Sintering Process. ISIJ Int. 2008, 48, 1517-1523. [CrossRef]

14. Yu, Z.; Fan, X.; Gan, M.; Chen, X.; Lv, W. NOx Reduction in the Iron Ore Sintering Process with Flue Gas Recirculation. JOM 2017, 69, 1570-1574. [CrossRef] 
15. Fan, X.; Yu, Z.; Gan, M.; Chen, X.; Chen, Q.; Liu, S.; Huang, Y. Elimination Behaviors of NOx in the Sintering Process with Flue Gas Recirculation. ISIJ Int. 2015, 55, 2074-2081. [CrossRef]

16. Chen, Y.; Guo, Z.; Feng, G. NOx reduction by coupling combustion with recycling flue gas in iron ore sintering process. Int. J. Miner. Metall. Mater. 2011, 18, 390-396. [CrossRef]

17. Zhao, J.P.; Loo, C.E.; Dukino, R.D. Modelling fuel combustion in iron ore sintering. Combust. Flame 2015, 162, 1019-1034. [CrossRef]

18. De Castro, J.A.; Yasushi, S.; Jun-ichiro, Y. Three dimensional mathematical model of the iron ore sintering process based on multiphase theory. Mater. Res. 2012, 15, 848-858.

19. Komarov, S.V.; Shibata, H.; Hayashi, N.; Kasai, E. Numerical and Experimental Investigation on Heat Propagation Through Composite Sinter Bed with Non-Uniform Voidage: Part I Mathematical Model and Its Experimental Verification. J. Iron Steel Res. Int. 2010, 17, 1-7. [CrossRef]

20. Yang, W.; Yang, K.; Choi, S. Effect of Fuel Characteristics on the Thermal Processes in an Iron Ore Sintering Bed. JSME Int. J. Ser. B 2005, 48, 316-321. [CrossRef]

21. Zhou, H.; Zhou, M.; Liu, Z.; Cheng, M.; Chen, J. Modeling NOx emission of coke combustion in iron ore sintering process and its experimental validation. Fuel 2016, 179, 322-331. [CrossRef]

22. Vanderheyden, B.; Van Loo, F.; Ojeda, C.; Mathy, C.; Steyls, D. Modelling Pollutants Formation and Behaviour during Sintering of Iron Ore; European Commission: Ispra, Italy, 2010.

23. Wang, G.; Wen, Z.; Lou, G.; Dou, R.; Li, X.; Liu, X.; Su, F. Mathematical modeling of and parametric studies on flue gas recirculation iron ore sintering. Appl. Therm. Eng. 2016, 102, 648-660. [CrossRef]

24. Wang, G.; Wen, Z.; Lou, G.; Dou, R.; Li, X.; Liu, X.; Su, F. Mathematical modeling and combustion characteristic evaluation of a flue gas recirculation iron ore sintering process. Int. J. Heat Mass Transf. 2016, 97, 964-974. [CrossRef]

25. Zhou, H.; Zhao, J.P.; Loo, C.E.; Ellis, B.G.; Cen, K.F. Numerical Modeling of the Iron Ore Sintering Process. ISIJ Int. 2012, 52, 1550-1558. [CrossRef]

26. Yang, W.; Ryu, C.; Choi, S.; Choi, E.; Lee, D.; Huh, W. Modeling of Combustion and Heat Transfer in an Iron Ore Sintering Bed with Considerations of Multiple Solid Phases. ISIJ Int. 2004, 44, 492-499. [CrossRef]

27. Crawford, C.W.; Plumb, O.A. The Influence of Surface Roughness on Resistance to Flow Through Packed Beds. J. Fluids Eng. 1986, 108, 343-347. [CrossRef]

28. Yang, W.; Ryu, C.; Choi, S.; Choi, E.; Ri, D.W.; Huh, W. Mathematical model of thermal processes in an iron ore sintering bed. Met. Mater. Int. 2004, 10, 493-500. [CrossRef]

29. Hobbs, M.; Radulovic, P.; Smoot, L. Combustion and gasification of coals in fixed-beds. Prog. Energy Combust. Sci. 1993, 19, 505-586. [CrossRef]

30. Nath, N.K.; Mitra, K. Mathematical Modeling and Optimization of Two-Layer Sintering Process for Sinter Quality and Fuel Efficiency Using Genetic Algorithm Combustion and gasification of coals in fixed-beds. Prog. Energy Combust. Sci. 2005, 20, 335-349.

31. Young, R.W. Dynamic Mathematical Model of (Iron-Ore) Sintering Process. Ironmak. Steelmak. 1977, $4,321-328$.

32. Irabien, A.; Viguri, J.R.; Ortiz, I. Thermal dehydration of calcium hydroxide. 1. Kinetic model and parameters. Ind. Eng. Chem. Res. 1990, 29, 1599-1606. [CrossRef]

33. Jóźwiak, W.; Kaczmarek, E.; Maniecki, T.; Ignaczak, W.; Maniukiewicz, W.; Maniecki, T. Reduction behavior of iron oxides in hydrogen and carbon monoxide atmospheres. Appl. Catal. A Gen. 2007, 326, 17-27. [CrossRef]

34. Karlström, O.; Brink, A.; Hupa, M. Biomass Char Nitrogen Oxidation-Single Particle Model. Energy Fuels 2013, 27, 1410-1418. [CrossRef]

35. Chambrion, P.; Kyotani, T.; Tomita, A. Role of N-Containing Surface Species on NO Reduction by Carbon. Energy Fuels 2012, 12, 416-421. [CrossRef]

36. Zhang, J.; Sun, S.; Hu, X.; Sun, R.; Qin, Y. Modeling NO-Char Reaction at High Temperature. Energy Fuels 2009, 23, 2376-2382. [CrossRef]

37. Yan-guang, C.; Zhan-cheng, G.; Zhi, W. Simulation of NO reduction by CO in sintering process. J. Iron Steel Res. 2009, 21, 6-9.

38. Goel, S.K. Environmental Problems: Fundamental Studies and Global Ramifications; Massachusetts Institute of Technology: Cambridge, MA, USA, 1996.

39. Hong, J.; Hecker W, C.; Fletcher T, H. Modeling high-pressure char oxidation using langmuir kinetics with an effectiveness factor. Proc. Combust. Inst. 2000, 28, 2215-2223. [CrossRef] 
40. Austin, P.R.; Nogami, H.; Yagi, J. A Mathematical Model for Blast Furnace Reaction Analysis Based on the Four Fluid Model. ISIJ Int. 1997, 37, 748-755. [CrossRef]

41. Wang, C.A.; Du, Y.; Che, D. Investigation on the NO Reduction with Coal Char and High Concentration CO during Oxy-fuel Combustion. Energy Fuels 2012, 26, 7367-7377. [CrossRef] 